Article

\title{
Economic Freedom and Income Inequality: Does Political Regime Matter?
}

\author{
Mahyudin Ahmad 1,2 \\ 1 Faculty of Business Management, Universiti Teknologi MARA Malaysia, Arau Perlis 02600, Malaysia; \\ mahyudin_77@yahoo.com; Tel.: +44-744-867-7168 \\ 2 Faculty of Economics, University of Cambridge, Sidgwick Avenue, Cambridge CB3 9DD, UK \\ Academic Editor: Ralf Fendel \\ Received: 15 November 2016; Accepted: 29 May 2017; Published: 5 June 2017
}

\begin{abstract}
There is a growing literature studying the effects of economic freedom and democracy on income inequality; nevertheless, the inequality-effects of both factors are apparently studied separately. This paper revisits the income inequality-economic freedom nexus and uncovers the role of political regime in explaining the relationship. Using the latest inequality data from Standardized World Income Inequality (SWIID) version 5.0 for a sample of countries up to 115 over 1970-2014 period, and via dynamic panel GMM estimation method, an inequality model that explicitly captures the interaction effect of economic freedom and democracy is estimated. The findings demonstrate that economic freedom has positive effect on income inequality. The estimated size of inequality-increasing effects of economic freedom is substantial, ranging between $0.3 \%$ and $0.5 \%$ per annum. Nevertheless, the findings show that the freedom-induced inequality is attenuated in the presence of a democratic regime in the countries under study. Furthermore, freedom of international trade and market deregulation are shown to be the two most consistently significant liberalization policies across the baseline estimations and various sensitivity tests. The paper is concluded with some policy implications.
\end{abstract}

Keywords: liberalization; economic freedom; democracy; income inequality; panel data

JEL Classification: O15; P48; C33

\section{Introduction}

Studies on the relationship of economic freedom and democracy to income inequality often take separate courses. In the liberalization literature, theoretically it is often argued that more economic freedom is associated with greater inequality. Nevertheless, empirical findings on the distributive effect of economic freedom remain ambiguous (see the most recent study on the economic freedom-inequality relationship by Bennett and Nikolaev (2016)). Similarly, in democracy studies, political economy scholars are frequently in support of the positive effect of democracy on income distribution, yet empirical evidence are still inconclusive (Acemoglu et al. 2015).

This paper seeks to provide a better understanding on the distributive effect of economic liberalization policy which it posits may differ according to regime types. This distinctive effect is captured in this study by including an economic freedom-democracy interaction term in the inequality model. Investigation into the freedom-democracy interaction effect on income inequality is vital since countries differing in term of liberalization and political regime may have different level of inequality.

For example, in the sample countries under study, Singapore is the most liberalized but a non-democratic country and Peru on the other hand is the least liberalized and a country that experiences some changes in its political regime. Yet Singapore has lower inequality level than Peru. So we may ask does liberalization improve income distribution? Or does a democratic regime give rise 
to inequality? Another example, Namibia and Bulgaria have somewhat similar level of freedom, but both differ in term of their political settings. Namibia is an always-democratic country but Bulgaria is a country that is in transition politically, nevertheless, Namibia has higher inequality than Bulgaria. So we may ask, again, for a given level of economic freedom, does income inequality differ according to the democratic settings of a country? This paper thus seeks to find the answers to these questions, and ultimately, aims to provide an evidence on the possible demarcated distributive effect of liberalization policy that follows specific regime types.

As proposed by Acemoglu et al. (2005), any market system and market-oriented policy-like economic liberalization-in a country is embedded in a larger political system that shapes economic institutions leading to economic development and income distribution. Different types of political regime may modify and influence the functions of market and economic institutions differently, and consequently the distributive effect of economic reform would be very much dependent on the nature of the political system.

To the best of our knowledge, only Amendola et al. (2013) and Reuveny and Li (2003) have attempted to study together the effects of both economic freedom and democracy forces on income distribution. However, Amendola et al. only focus on developing countries, while Reuveny and Li on the other hand suffer various empirical shortcomings. ${ }^{1}$ Both studies furthermore do not investigate the interaction effect of economic freedom-democracy on inequality.

Overall, this paper contributes to the existing literature in three ways. First it examines the role of democratic regime which has been previously invariably omitted in the economic freedom-inequality studies. It seeks to determine whether a given political regime would attenuate or exacerbate the effect of liberalization policy on income distribution. Secondly, it investigates deeper into the inequality-effect of liberalization by using five areas of economic freedom, in addition to its overall freedom index, which hitherto has been very limited in the existing economic freedom-inequality literature (Bergh and Nilsson 2010). Finally, it utilizes the most complete inequality data obtained from the latest SWIID version 5.0 dataset that accounts for the uncertainty in the Gini coefficients. Additionally, it employs an almost extensive classification of political regime from four different sources, together with a large dataset covering up to 115 developed and developing countries over a period of 45 years between 1970 and 2014, and a panel GMM estimation technique that is capable of overcoming endogeneity issue, unobserved heterogeneity and omitted variable bias, and measurement errors.

The baseline inequality estimations yield positive and statistically significant coefficients of economic freedom and democracy, demonstrating the inequality-increasing effects of both factors. However, the interaction term is found to be negatively and significantly associated with income inequality which is subsequently interpreted as income-equalizing effect of liberalization policy when it is implemented by a democratic regime. Overall, the estimated size of inequality-increasing effect of economic liberalization in a non-democratic regime is around $0.27-0.5 \%$ per annum. Nevertheless, in a democratic regime, similar liberalization policy is able to reduce inequality by $0.13-0.6 \%$ per annum. Finally, for a given level of economic freedom in the countries under study, a democratic regime is expected to raise inequality by approximately $0.33-0.8 \%$ annually. ${ }^{2}$

Deeper investigation shows that freedom of international trade and market deregulation are the two most consistently significant liberalization policies. These findings stand a battery of tests for its robustness, in which alternative variables for inequality and democracy variables, different set of control variables, and various country sub-samples based on economic development are used. Besides, the robustness of inequality-increasing effect of economic freedom is also tested in sub-samples based on the regime types.

See Timmons (2010) for more discussion on the econometric problems of Reuveny and Li (2003).

A necessary caveat is required when interpreting the inequality-effect of democracy, and it is discussed more in the results section. 
The study proceeds as follows: Section 2 reviews the literature on the theoretical links of economic liberalization and democracy to income inequality, followed by discussion on previous empirical studies regarding the distributive effects of both factors. In Section 3, data, econometric specification and empirical strategy to estimate the relationship between the variables of interest are discussed. Section 4 presents and discusses the estimation results and Section 5 concludes with some policy recommendations.

\section{Review of Literature on Income Inequality Links to Liberalization and Democracy}

\subsection{Inequality and Economic Liberalization}

Generally, economic liberalization is related to market-oriented reform with the aim of creating an environment conducive for market-supported personal and voluntary exchanges, freedom to enter and compete in the market, as well as freedom of ownership of property with protection against aggression by others. According to Fraser Institute, Economic Freedom in the World (EFW) index is designed to measure the extent to which the institutions and policies of a nation are consistent with this protective function and the freedom of individuals to make their own economic decisions. The EFW index consists of five main areas and each area contains a number of institutional and policy components. In the following, the coverage of each of the five areas of the EFW and their theoretical links to income inequality are briefly discussed ${ }^{3}$ :

1. Size of government: This component measures government size via indicators like government consumption and transfers as a share of GDP, state-owned enterprises, and top marginal tax-rates. It is coded in a way that larger size of government received less freedom score. Thus, a positive relationship to income inequality is expected since larger government normally leads to lower inequality. In other words, larger government size as a result of greater welfare spending and increased public sector transfers is expected to reduce income gap as such spending and transfers are meant for various income-equalizing policies like child benefits, free education and healthcare etc.

2. Legal system and property rights: This component focuses on the protection of property rights via rule of law, independent and unbiased judiciary, and impartial and effective enforcement of the law. Intuitively, protection of property rights is thought to mainly benefit those with properties which are normally the high income earners. Protection increases the value of the properties leading to rising earnings of this group, and consequently creating a larger gap with the low income earners in the country. Thus, we may expect a positive relationship of this component to inequality.

3. Access to sound money: Economic exchanges require money. This component receives low scores when the value of money is volatile due to inflationary pressure and unpredictable monetary policy. Thus, a negative association with income inequality is expected since the cost of inflation in term of returns to capital and lending rates are expected to be relatively more detrimental to low income earners whose assets are less protected against inflation. This leads to wider gap between the top and bottom earners within a population.

4. Freedom to trade internationally: This component captures various protectionist measures like trade taxes, tariff rates and trade barriers and capital market controls. According to Heckscher-Ohlin theory, openness to international trade is expected to reduce (increase) income inequality in developing (developed) countries. This is because increased demand for low skilled workers that are abundant in developing countries is expected to exert a downward pressure on the

3 See https://www.fraserinstitute.org for more information on the economic freedom index definition, areas and methodology to compute the index. For a more detailed discussion on the theoretical links and empirical evidence of five areas of economic freedom to inequality, see Bergh and Nilsson (2010). 
wage gap between skilled-unskilled labors. Nevertheless, this proposition is still debatable due to differing theoretical approximations taking into account degrees of openness, different assumptions in term of factors supply and mobility, and unequal level of technology between the trading countries.

5. Regulation of credit, labor and business: The final component of EFW focuses on the regulatory constraints that limit the freedom of exchange in credit, labor and product markets. Deregulation provides greater access to credit to all population segments including the low income earners to support their economic ventures and this subsequently may improve their incomes. Nevertheless, positive distributive effect of deregulation may not be realized in a situation when political elites can influence the deregulation policy. Therefore, there is no clear indication in the direction of inequality-effect of this component.

The empirical evidence of the inequality-effect of economic freedom is apparently inconclusive. Bennett and Nikolaev (2016) review the previous studies on the income inequality-economic freedom relationship and suggest that empirical heterogeneity is the reason behind the mixed findings (i.e., different choice of econometric models, country sample, time period and/or inequality and freedom measures used in the studies). On a similar note, Holcombe and Boudreaux (2016) argue that the relationship of market institutions, proxied by economic freedom, to income inequality is ambiguous as a result of different inequality measures even though an identical estimation is used.

The following is a brief collection of economic freedom-inequality studies grouped according to their findings. Studies that find inequality-reducing effect of economic freedom are such as Clark and Lawson (2008); Bennett and Vedder (2013)-in a study on 50 U.S. states; Scully (2002)-although he also finds a positive freedom indirect effect on inequality via growth; Carter (2006); and Apergis and Cooray (2015)-the latter two studies also find a U-shape non-linear relationship between economic freedom and inequality. On the other hand, there are also studies finding economic freedom leads to higher inequality, such that of Berggren (1999)-positive effect for level of economic freedom, but negative effect of 10-year changes in economic freedom; Bergh and Nilsson (2010)-for overall index of economic freedom and for freedom to international trade component; Bennett and Cebula (2016); Bennett and Nikolaev (2016)-for both Gini measurement based on gross and net incomes, but they also find a non-linear relationship between economic freedom and inequality i.e., economic freedom is associated with more (less) inequality at lower (higher) level of freedom. Sturm and Haan (2015) however find no robust relationship.

\subsection{Inequality and Democracy}

Democracy is frequently portrayed as a harbinger of numerous social benefits including income equality. The role of democracy in income distribution is consequently increasingly becoming the subject of intense debate by many scholars.

According to Freedom House, democratization refers to the process through which citizens in a political regime acquire more political rights and civil liberties. Political Rights refer to free and fair elections, the existence of elected rulers, competitive political parties and other political groups, strong opposition, and the minorities are well represented in politics and government. Civil Liberties meanwhile refer to freedom of expression, assembly, association, education, and religion, established and fair legal system that ensures the rule of law, and equal opportunity for everyone in the country. An average of the ratings of the two indicators above is called freedom rating; a high (low) freedom rating is often used as an indicator of democracy (autocracy). ${ }^{4}$ A summary of theoretical arguments

4 For more details, see https://freedomhouse.org/report/methodology-freedom-world-2017. 
explaining how a democratic regime is expected to bring about a more egalitarian distribution of income in society is as the following: ${ }^{5}$

1. Median voter theory: This theory argues that, based on rational choice of redistribution, the median voters would choose redistribution and higher taxation for rich people if the median income lies below the mean income. This theory thus predicts that income inequality is lower in a democracy than an autocracy.

2. Political participation mechanism: Via this mechanism, democracy is expected to lower the costs of political participation, giving rise to strong and organized labor unions, political parties and interest groups representing the low and middle income groups. These groups would then push for more welfare-augmenting policies such as minimum wage that reduce wage dispersion.

3. Political competition mechanism: This mechanism highlights the importance of electoral connection. Reelection-oriented democratic leaders would compete for citizen support, and consequently invest more in meeting the needs of the larger segments of suffrage who are normally the low and middle income earners. To win the voters' support, they would adopt various redistributive measures such as welfare spendings and benefits, greater access to education and healthcare, price subsidies, and other public services provisions.

On the other hand, Acemoglu et al. (2015) also consider the opposite theoretical proposition i.e., democracy may result in a more unequal income distribution. They propose three possible ways for such outcome to happen. Firstly, if, as a result of democratization, the richer segments of population invest in increasing their de facto power (via lobbying, control of local law enforcement, and other means of capturing the party system) to compensate for the loss of their de jure power, a government with captured interests is therefore expected to constrain redistribution and consequently inequality may still persist. Secondly, based on the "Director's Law" premise, increased tax revenues in a democracy may only be allocated to middle class group, and not redistributed to the larger poor group of population since it is not favored by the middle class group. Finally, drawing examples from post-apartheid South Africa and post-Soviet Union transition countries, democratization may result in higher inequality due to what is termed by Acemoglu et al. as "Inequality-increasing market opportunities".

As is the case with empirical studies on the economic freedom and inequality, the findings on inequality-democracy relationship is similarly far from a consensus. This is further confounded by the unique experience of countries such as in Asian region that display low income inequality and low-rating democratic institutions, and in Latin America whose higher-rating democratic institutions are not matched with an improved income distribution (Savoia et al. 2010). In general, the empirical findings of the democracy-inequality studies are mixed, divided between mostly negative and no impact, and some results are argued as not robust due to various econometric issues including endogenous of democracy, omitted variable bias, measurement error and unobserved heterogeneity. ${ }^{6}$

Briefly, studies finding support for the inequality-reducing effect of democracy are like Balcázar (2016); Islam (2016); Reuveny and Li (2003); Lee (2005)-democracy reduces inequality only when the government size is large; Gradstein and Milanovic (2004); and Gerry and Mickiewicz (2008)-the latter two studies are on the former communist countries, but Gradstein and Milanovic only find a weak evidence; while Amendola et al. (2013) and Ahmad (2016) only find an indirect negative effect of democracy on inequality via property right institutions and economic liberalization, respectively. Finally, Timmons (2010) and Acemoglu et al. (2015) find no robust relationship at all between democracy and economic inequality.

5 The summary is briefly extracted from a longer discussion found in Acemoglu et al. (2015), Balcázar (2015), Reuveny and Li (2003) and Timmons (2010).

6 For detail discussion on the empirical heterogeneity of democracy-inequality studies, see Acemoglu et al. (2015) and Balcázar (2016) 


\section{Data, Econometric Specification and Empirical Strategy}

\subsection{Data}

This study uses an unbalanced panel dataset covering a total of 115 countries over a period of 45 years from 1970 to 2014. Since the data are unbalanced, number of countries in the estimation would vary depending on the availability of data. All observations are taken as average of 5-year period, thus there are 9 non-overlapping 5-year periods i.e., 1970-1974, 1975-1979, 1980-1984, 1985-1989, 1990-1994, 1995-1999, 2000-2004, 2005-2009, and 2010-2014. The summary statistics of the variables used in this study are presented in Table A1 in the Appendix A.

Dependent variable: This study acknowledges the fact that measuring inequality is inarguably a methodologically challenging task due to differences in income definition either based on gross income, net income or expenditure, and differences in unit of measurement either household or individual. These issues have undoubtedly caused a concern over the inequality data's quality and comparability across countries and over times. Therefore, in this study, Gini coefficient from Standardized World Income Inequality Database (SWIID) created by Solt (2014) is used as the preferred measure of income inequality due to its superiority in term of availability and comparability for cross-country research. ${ }^{7}$ Furthermore, the latest SWIID data version 5.0 takes into account the uncertainty in the predicted measure of inequality by using multiple imputed estimation techniques that automate the Monte Carlo simulation process and average the results to arrive at the final measure of inequality (Solt 2014).

Gini coefficient of net income is used and since the Gini is bounded between 0-100, the Gini coefficient is transformed into an unbounded measure using this formula [Gini/(100-Gini)], and subsequently the unbounded measure is converted into a natural log value. Additionally, in the sensitivity analysis to ensure the robustness of the baseline results, alternative inequality measures are used namely the SWIID original bounded measure Gini of net income, unbounded Gini of gross income, and a measure of inequality obtained from Estimated Household Income Inequality (EHII) dataset provided by University of Texas Inequality Project (UTIP) (Galbraith et al. 2014) ${ }^{8}$. The EHII dataset is particularly important for sensitivity analysis as it is not part of the various inequality measures used by Solt in the standardization exercise to create the SWIID data.

Independent variables: There are two variables of interest in this study, firstly economic freedom variable which is drawn from Economic Freedom in the World (EFW) dataset obtained from the Fraser Institute (Gwartney et al. 2010). EFW is a composite index that covers large number of countries since 1970 starting with 5-yearly data and beginning 2000 available annually. As is discussed in the literature review section, it weighs together five areas of economic freedom namely:

(a) size of government (henceforth denoted EFW1),

(b) legal system and property rights (EFW2),

(c) access to sound money (EFW3),

(d) freedom to trade internationally (EFW4), and

(e) regulation of credit, labor, and business (EFW5).

The EFW index and its five areas have a range of scores from 0 to 10 , where 0 indicating the least freedom and 10 greatest freedom. ${ }^{9}$

7 See Bergh and Nilsson (2010) for discussion on the superiority of Gini coefficient from SWIID as compared to World Income Inequality Database (WIID) of UNU-WIDER, Standardized Income Distribution Database (SIDD) created by Babones and Alvarez-Rivadulla (2007) or Luxembourg Income Study (LIS) etc. On the other hand, Jenkins (2015) recommends the use of WIID over SWIID although his recommendation is conditional. It is noteworthy that Jenkins, in discussing his concern regarding SWIID imputation exercise that may lead to the risk of bias estimates, refers to SWIID version 4.0, and this paper uses the latest SWIID version 5.0.

8 EHII dataset is downloadable at http:/ / utip.gov.utexas.edu and available up until to 2008 only.

9 Table A3 in Appendix A lists the complete coverage of data to calculate the composite index of EFW 
The other variable of interest is an indicator for regime types in the countries under study. The preferred measure of regime types is Imputed Polity 2 variable obtained from Hadenius and Teorell (2007). This democracy variable (henceforth denoted IP2), is based on two data sources namely the Freedom House's Freedom in the World dataset and Marshall and Jaggers (2014)'s Polity IV dataset. ${ }^{10}$ According to Hadenius and Teorell, this imputed version of Polity 2 performs better both in terms of validity and reliability than its constituent parts. Although the original score of Imputed Polity 2 by Hadenius and Teorell is continuous from 0 (least democratic) to 1 (most democratic), in this paper, the score is rescaled into a dichotomous 0 and 1 where 0 indicates an autocratic regime, and $1 \mathrm{a}$ democratic regime.

Specifically, a country political regime is classed as "always democracy" when the country has democracy score, dem $=1$ for all periods under study. If the country has dem $=0$ for all periods, it is classed as "always non-democracy". The final class is called "in-transition" since several countries in the sample experience some political transition, reflected by their dem score that changes between $0-1$, during the periods under study. For example, there are some countries that transition into democracy and permanently stay in democracy after the transition like Bulgaria in 1990, Hungary in 1990, and Spain in 1978 (majority of our countries in-transition experience this type of transition, i.e., they democratize); there are also countries that transition in and out of democracy like Argentina which is in our data coded as a democratic in 1970-75, then a non-democratic in 1976-1984 and reverts to democracy after that, or Bangladesh a democratic country in 1970-75, then a non-democratic between 1975-1989, only to become a democratic again beginning 1990 onwards; and there are also countries earlier in the sample are classed as democracy but have transitioned out into non-democracy later in the sample, for example Venezuela and Russia. ${ }^{11}$

The main reason a dichotomous indicator is used is that it represents the most convenient and straightforward way to segregate the countries according to regime types. Recall the main objective of the paper is to investigate the distributive effect of economic freedom which is posited to differ under different regimes. Thus, by using dichotomous, not continuous, indicator of democracy, the focus of the paper is only on the regime types, and not on the process of democratization (which is inarguably well-represented by a continuous indicator). Furthermore, in the sensitivity analysis, the alternative democracy indicators used are that of Acemoglu et al. (2015), Boix et al. (2013) and Cheibub et al. (2010), all of which are dichotomous. Again, the use of a rescaled score of Imputed Polity 2 variable to reflect regime types, instead of the original continuous score, is naturally appropriate and robust for sensitivity testing purpose.

The following Table 1 presents summary statistics of the Gini and the economic freedom variables for the sample countries under study. The summary statistics of both variables according to regime type sub-samples based on the dichotomous democracy variable IP2 are also presented. As is seen in Table 1, the overall mean of Gini coefficient is 36.93 with standard deviation of 9.58 , while the overall mean of economic freedom score 6.26 out of 10 with standard deviation of 1.25 . One important feature from the statistics in Table 1 below is that democratic countries in general have lower than average inequality but greater than average economic freedom, so do high income countries. Intuitively, it may be presumed that high income nations are generally democratic. This is an important finding since the

10 Specifically, the average score of political rights and civil liberties is transformed to a scale $0-10$, as is Polity 2 score of -10 to 10. Subsequently these transformed scores are averaged into an imputed version of Polity 2 with final score between $0-10$. In the event that data on Polity 2 is missing, this imputed version generate imputed values for countries by regressing Polity 2 scores on the average Freedom House measure.

11 Venezuela status as a "partly free" country is remarked as trending down after the election of new president following the death of Chavez in 2012—-see the country's detailed report especially in year 2014 onwards on the Freedom House website here: https:/ / freedomhouse.org/report/freedom-world/2014/venezuela. In the latest 2017 report, Venezuela however is now classed as "not free." Meanwhile Russia has been classed as "not free" since 2005, prior to that year was classed "partly free." 
focus of this study is to investigate the differences in the inequality-effect of liberalization policy when it is implemented by different regime types.

A closer inspection on the statistics shows that Bulgaria has the lowest inequality while Namibia has the highest. Bulgaria is a country in-transition while Namibia is an always democratic country, and both has somewhat equal freedom score around 6 during the period of study. If democracy is perceived to reduce inequality as the theory suggests, it may be assumed that Namibia would have lower Gini value than Bulgaria, but this is not the case. Meanwhile, Peru is shown to be the least free country and Singapore is the freest. As far as their democratic setting is concerned, Peru is a country in-transition but Singapore is a non-democratic country. Again, the theoretical argument would suggest that a country with the most economic freedom is expected to have higher inequality than a country that is less free. This is again not the case, as Singapore's Gini level at around 40.2 is much lower than Peru's which is at around 52.2.

Table 1. Summary statistics for inequality and economic freedom variables for overall and sub-samples.

\begin{tabular}{|c|c|c|c|c|c|c|}
\hline Country Sample & Mean & Std. Dev. & Minimum & Maximum & Obs. & No. of Countries \\
\hline Overall sample & 36.93 & 9.58 & 16.11 (Bulgaria) & 65.72 (Namibia) & 789 & 115 \\
\hline In-transition & 39.00 & 8.60 & 16.11 (Bulgaria) & 61.47 (Sierra Leone) & 326 & 46 \\
\hline Always non-democracy & 40.57 & 6.45 & 25.35 (Rwanda) & 58.21 (Egypt) & 87 & 14 \\
\hline High income & 30.02 & 6.51 & 17.29 (Slovakia) & 51.07 (Chile) & 323 & 42 \\
\hline Lower middle income & 40.97 & 7.79 & 19.99 (Ukraine) & 61.25 (Kenya) & 170 & 26 \\
\hline Low income & 42.19 & 7.35 & 25.35 (Rwanda) & 61.47 (Sierra Leone) & 80 & 16 \\
\hline \multicolumn{7}{|c|}{ Economic Freedom Overall Index, EFW } \\
\hline Overall sample & 6.26 & 1.25 & 2.5 (Peru) & 8.9 (Singapore) & 726 & 115 \\
\hline Always democracy & 6.78 & 1.04 & 2.9 (Nicaragua) & 8.8 (New Zealand) & 340 & 55 \\
\hline Lower middle income & 5.73 & 1.12 & 2.9 (Nicaragua) & 7.7 (Armenia) & 154 & 26 \\
\hline Low income & 5.26 & 1.01 & 2.8 (Uganda) & 7.4 (Rwanda) & 77 & 16 \\
\hline
\end{tabular}

As is earlier mentioned, three other alternative measures of democracy are used for sensitivity analysis of the results. They are a dichotomous democracy measure obtained from Acemoglu et al. (2015)—-henceforth ANRR; Boix et al. (2013)—henceforth BMR; and a classification of political regimes by Cheibub et al. (2010)-henceforth CGV. ANRR's dichotomous measure of democracy is naturally closer to the preferred democracy variable IP2 as they too refer to the Freedom House country classification of "free", "partly free" and "not free" and cross-checked against the Polity 2 scores. ANRR classify free or partly free countries with positive Polity 2 score as "democratic" and if no information about a country from either Freedom House or Polity 2, ANRR refer to country classification of BMR or CGV. Similarly, BMR democracy dataset provides a dichotomous coding of democracy i.e., a country is classed as a democracy if it satisfies conditions for both contestation and participation, features a free and fair election to elect political leaders and satisfies a threshold value of suffrage. Meanwhile, CGV classification of political regime states that a regime is considered a democracy if the executive and the legislature is directly or indirectly elected by popular vote, multiple parties are allowed, there is de facto existence of multiple parties outside of regime front, there are multiple parties within the legislature, and there has been no consolidation of incumbent advantage (e.g., unconstitutional closing of the lower house or extension of incumbent's).

The following Table 2 illustrates the pairwise correlation matrix between economic freedom EFW index and its five areas and four democracy variables used in this study. As is seen in the table, high correlation between the overall index of EFW and its five areas is not unexpected since the areas constitute the overall index value. Several areas of economic freedom are closely related to each 
other but the correlation value does not exceed 0.7, with the exception of EFW3 and EFW4 which is correlated at 0.695 . Since each of the five areas of economic freedom is included in separate individual estimations, this is not an issue altogether. Meanwhile, all four democracy measures are highly correlated, especially IP2 and ANRR. This is not surprising since both IP2 and ANRR classifications are based on the information from Freedom House and Polity 2 variables. The correlation between BMR and CGV to IP2 and ANRR is however slightly lower at around 0.8 , and this is expected since IP2 and ANRR indicate substantive changes in political power, whereas classification of regimes by BMR and CGV are more procedural (Acemoglu et al. 2015). Since these democracy variables are used for sensitivity analysis, high correlation between them shows that they are indeed good alternative to each other.

Table 2. Correlation matrix between EFW dimensions and democracy variables.

\begin{tabular}{cccccccccc}
\hline & EFW & EFW1 & EFW2 & EFW3 & EFW4 & EFW5 & IP2 & ANRR & BMR \\
\hline EFW1 & 0.236 & & & & & & & & \\
EFW2 & 0.686 & -0.268 & & & & & & & \\
EFW3 & 0.843 & 0.056 & 0.514 & & & & & & \\
EFW4 & 0.868 & 0.030 & 0.637 & 0.695 & & & & & \\
EFW5 & 0.792 & 0.219 & 0.456 & 0.587 & 0.598 & & & & \\
IP2 & 0.395 & 0.019 & 0.292 & 0.270 & 0.445 & 0.379 & & & \\
ANRR & 0.384 & 0.015 & 0.282 & 0.263 & 0.442 & 0.370 & 0.963 & & \\
BMR & 0.392 & -0.032 & 0.330 & 0.305 & 0.448 & 0.336 & 0.806 & 0.809 & \\
CGV & 0.388 & 0.028 & 0.293 & 0.299 & 0.436 & 0.318 & 0.787 & 0.796 & 0.875 \\
\hline
\end{tabular}

Finally, a set of control variables is also included in the estimation model. It comprises of several correlates of income inequality gathered from the existing literature. Firstly, real GDP per capita, and data for this variable in million US dollar at a constant 2011 price are obtained from Penn World Table 9.0 (Feenstra et al. 2015). To account for the Kuznets' theory that predicts a non-linear impact of GDP per capita on inequality, real GDP per capita squared is included in all regressions. Next, tertiary education level, which is frequently shown to strongly determine the skill differences and consequently wage premiums among the workers, and this variable is proxied by data on the share of population age 25 and above who have completed tertiary education obtained from Barro and Lee (2013). The model also controls for age dependency ratio i.e., the share of population size whose age is outside working age range (15-64) to the size of labor force. Larger dependency ratio is expected to reflect large income inequality among the population. Finally, employment in industrial sector, employment in service sector and urban population, added to capture any specific effect these factors could have on the level of inequality in a country. Data for the last four control variables are obtained from the World Development Indicators (World Bank 2016). Table A2 in the appendix show the pairwise correlation matrix of the included variables.

\subsection{Econometric Specification}

To provide some robust findings about the role of democracy in the economic freedom-inequality relationship, the following empirical specification is formulated:

$$
\operatorname{gini}_{i t}=\alpha+\beta_{1} \text { gini }_{i t-1}+\beta_{2} e f w_{i t-1}+\beta_{3} \operatorname{dem}_{i t-1}+\beta_{4}\left(e f w_{i t-1} \times d e m_{i t-1}\right)+x_{i t}{ }^{\prime} \gamma+\eta_{i}+\rho_{t}+\varepsilon_{i t}
$$

where, gini is the dependent variable in natural log form, gini $i_{i-1}$ is the lagged dependent variable, $e f w$ is the economic freedom variable as a proxy for economic liberalization, dem is the variable that reflects political regime in a country, $x$ is the set of control variables as earlier discussed, and $\eta$ and $\rho$ is a full set of country and time dummies respectively. Finally, $\varepsilon$ is i.i.d. error term capturing all other omitted factors. The subscript ' $i$ ' and ' $t$ ' is for country and time period, respectively, and $\beta_{1}-\beta_{4}$ are the parameters of interest to be estimated. 
Via Equation (1), the model hypothesizes that income inequality is determined by two variables of interest namely economic freedom and democracy and their interaction, alongside its lagged values, a set of other control variables, and a set of dummies capturing country- and time-specific effects. As is previously discussed in the introduction section, the main objective of this paper is to investigate the distinctive distributive effect of a liberalization policy according to regime types. In Equation (1) above, this is explicitly captured by the inclusion of the interaction term between economic freedom and democracy. The total effect of economic freedom on income inequality therefore can be gauged by taking partial derivative of gini with respect to $e f w$, as the following:

$$
\frac{\partial g i n i}{\partial e f w}=+\beta_{2}+\beta_{4} d e m
$$

Because of the democracy data is a dichotomous indicator of $1-0$ where 1 denotes a democratic regime and 0 a non-democratic regime, the effect of economic freedom in a democratic regime is represented by the sum of $\beta_{2}+\beta_{4}$, but the effect of economic freedom in a non-democratic regime is reflected by coefficient $\beta_{2}$ only since dem $=0$. Meanwhile, the partial effect of democracy, holding other factors including economic freedom constant, is represented by $\beta_{3} .{ }^{12}$ Building on the theoretical discussion in the literature review section, the effect of economic freedom on inequality, holding other factors constant (which also means the effect of freedom in a non-democratic regime), is postulated to be inequality-increasing ( $\beta_{2}$ is positive). The effect of a democratic regime on inequality meanwhile is expected to be income-equalizing ( $\beta_{3}$ is negative). Total inequality-effect of economic freedom in a democratic regime, on the other hand, is expected to be attenuated by the presence of the democratic regime (therefore a negative sign for $\beta_{4}$ ). The following are the summary of the hypotheses:

Hypothesis 1. Liberalization, proxied by economic freedom, increases income inequality.

Hypothesis 2. Democracy reduces income inequality.

Hypothesis 3. The presence of a democratic regime attenuates the inequality-increasing effect of economic liberalization.

The focus of this paper however is on the Hypothesis 1 and 3 as it seeks to examine the possible demarcated liberalization effect on income inequality as a result of differing regime types. Although inequality-effect of democracy can be examined from the democracy coefficient $\left(\beta_{3}\right)$, a necessary caution must be exercised in its interpretation, as is later discussed in the results section.

\subsection{Empirical Strategy}

To test the above hypotheses, a canonical panel data model allowing for country fixed effects and time effects while also modelling the dynamics of inequality is estimated. Including country fixed effects is to control for potential bias originating from various characteristics of democracies and non-democracies which are distinctive and permanent yet unable to be observed in the model. Similarly, including lagged Gini would allow for mean-reverting dynamics and persistent effects of inequality to be captured in the model. This is consistent with the observed tendency of inequality to persist over time. Theoretically, the persistence may be caused by various factors such as political arrangements favoring wealth owners; racial discrimination resulting in ethnic income differences; socio-economic level influencing marriage decision i.e., people tend to marry those from the same socio-economic

12 The other partial derivative is when we take $\partial g$ gini/Jdem $=+\beta_{3}+\beta_{4} e f w$ which examines the inequality-effect of democratization for a given level of economic freedom in the country under study. Nevertheless, our interpretation on the effect of democratization always assume economic freedom to be constant. This is since the focus of the study is to examine the role of democracy in the economic freedom-inequality nexus, which is captured by Equation (2). 
group, and consequently their children would remain in the original group perpetuating income differences across groups; and costly education only the rich could afford leaving the poor to remain less educated and as a result continue to have lower income, ensuring the vicious circle (Reuveny and Li 2003).

From the empirical perspective, the presence of lagged Gini may cause an endogeneity issue as it could be a determinant of liberalization or democracy or may be correlated with other variables that predict these two variables of interest. Additionally, the presence of other variables on the right hand side of the model (for example real GDP per capita which have been found to correlate with democracy and liberalization) would also cause endogeneity and controlling for such variable is necessary as it may affect inequality independently of the influence of democracy and economic freedom on inequality.

To estimate Equation (1), this paper employs Difference Generalized Method of Moments (Difference GMM) introduced by Arellano and Bond (1991). ${ }^{13}$ A simplified version of Equation (1) and time-differencing process of Difference GMM estimator is discussed as follows:

$$
y_{i t}=\alpha y_{i t-1}+X_{i t}^{\prime} \beta+\eta_{i}+\rho_{t}+\varepsilon_{i t}
$$

where $y$ is Gini variable, $X$ represents the set of explanatory variables other than lagged Gini, $\eta$ is an unobserved country-specific effect, $\rho$ is time-specific effect, $\varepsilon$ is the i.i.d. error term. Time differencing of Equation (3) eliminates the country fixed effect $\eta$ and transforms the equation into:

$$
\Delta y_{i t}=\alpha \Delta y_{i t-1}+\Delta X_{i t}^{\prime} \beta+\Delta \rho_{t}+\Delta \varepsilon_{i t}
$$

Time-differencing checks for unobserved heterogeneity and omitted variable bias, as well as for time-invariant component of the measurement error. Via the use of instruments, the differenced estimator deal with the endogeneity problem resulted from the endogenous explanatory variables and from the construction of the new error term $\Delta \varepsilon_{i t}=\left(\varepsilon_{i t}-\varepsilon_{i t-1}\right)$ that is correlated with the lagged dependent variable, $\Delta y_{i t-1}=\left(y_{i t-1}-y_{i t-2}\right)$. Under the assumptions that (a) error term is not serially correlated, and (b) the explanatory variables, $X$, are weakly exogenous (i.e., the explanatory variables are assumed to be orthogonal to future realizations of the error term) the Difference GMM estimator uses the following moment conditions:

$$
\begin{aligned}
& E\left[y_{i t-s} \Delta \varepsilon_{i t}\right]=0 \text { for all } s \geq 2, t=3, \ldots, T \\
& E\left[X_{i t-s} \Delta \varepsilon_{i t}\right]=0 \text { for all } s \geq 2, t=3, \ldots, T
\end{aligned}
$$

in order to identify the valid lagged levels of explanatory variables to be used as instruments for the differenced equation. Normally, number of instrument lag is restricted since unrestricted lag of instruments (i.e., when full set of moments are used) in GMM may lead to instrument bias (Roodman 2009).

Validity of the instruments is necessary to yield unbiased and consistent GMM estimators. As suggested by Arellano and Bond (1991), Arellano and Bover (1995), and Blundell and Bond (1998), two specification tests are used. Firstly, Hansen test of over-identifying restrictions which tests for overall validity of the instruments and the null hypothesis is that all instruments as a group are

13 Ordinary Least Square (OLS) estimation therefore is straightforward biased since the estimation does not allow for the presence of fixed effects in the model. Furthermore, we follow Acemoglu et al. (2015) in not using Arellano and Bover (1995) and Blundell and Bond (1998) System GMM estimation. System GMM is an estimation that combines the difference equation with a level equation. Lagged levels are used as instruments for the endogenous variables in the differenced equation, whereas in level equation lagged first differences of the endogenous regressors are used as instruments. For consistency, System GMM estimator requires that the initial value of democracy and economic freedom variables to be uncorrelated with the fixed effects, however this is unlikely to be a good assumption given the historically determined nature of democracy and free market-oriented institutions. 
exogenous. The second test examines the null hypothesis that error term of the differenced equation is not serially correlated particularly at the second order (AR2). ${ }^{14}$ Ones should not reject the null hypothesis of both tests. Once these specification tests are fulfilled, GMM difference estimator is generally expected to remove any mechanical bias resulting from the presence of fixed effects and lagged dependent variables in the estimated model.

The empirical strategy begins with preliminary fixed effect estimation of various specifications to determine the most robust inequality model i.e., it starts with economic freedom variable as the only variable of interest in the model, then democracy is used as the only variable of interest, and then both economic freedom and democracy are included as the variables of interest, followed by a specification that contains both variables and their interaction term. Subsequently, economic freedom squared is added to test for its non-linear effect on inequality, and finally, a general model containing lagged Gini, economic freedom, democracy, and their interaction is specified. All the above specifications include control variables, time and country dummies.

Once the most robust model specification is determined, the study proceeds with the baseline estimation via fixed effects and difference GMM methods. Firstly, it estimates a model using the overall economic freedom variable, followed by estimations using each of the five areas of economic freedom. In all baseline estimations, democracy variable is present, and so is the interaction term with economic freedom variables. Via this strategy, the paper intends to examine the effect of freedom and democracy on income inequality, and seeks to uncover the inequality-effect of freedom policy when it is implemented by a specific regime type. In this baseline estimation, a full set of control variables and time and country dummies are present.

To mitigate endogeneity bias in fixed effects estimation, the variables of interest on the right hand side are lagged by one lag, with the assumption that economic freedom and democracy has no contemporaneous effect on inequality. ${ }^{15}$ For Difference GMM estimation, lagged Gini is assumed to be a predetermined variable, and economic freedom (the overall index and the five sub-areas), democracy, real GDP per capita, and human capital to be potentially endogenous. The number of instrument lags for predetermined variable is set to one period and potentially endogenous regressors to two to three periods. With this, the impacts of economic freedom, democracy, their interaction, and the endogenous control variables on inequality are postulated to be non-contemporaneous and will take within ten to fifteen years to affect a causal change to the present income distribution. ${ }^{16}$

STATA command $x$ tabond 2 is used to run the Difference GMM estimation and two-step robust option is employed to get the finite-sample corrected two-step covariance matrix that ensures the resulting standard errors are consistent with panel specific autocorrelation and heterokedasticity in one-step estimation (Windmeijer 2005). Finally, panel fixed effects estimation results are also reported for the baseline model to afford an appropriate comparison to the earlier studies using such method. Nevertheless, caution is needed when interpreting the results of fixed effect estimators due to the presence of lagged dependent variable which would be, by construction, correlated with the error term and therefore the estimators are downward biased.

Finally, the paper tests for sensitivity of the baseline results by using alternative inequality measures, alternative democracy measures, different set of control variables, as well as by different sub-samples based on income level. Furthermore, and since the focus of this study is to understand the distributive effects of freedom policy in a democratic versus non-democratic regime, the country

14 By construction, the differenced error term is probably serially correlated at first-order even if the original error is not. While most studies employing GMM estimation report the test for first order serial correlation, some do not.

15 Note that one-period lag of the variable of interests in Equation (1) always means a 5-year lag, since the data are 5-year average across the sample year 1970-2014. The practice to predate endogenous regressors as a way to handle endogeneity has also been done by Berggren (1999), Bergh and Nilsson (2010), and Acemoglu et al. (2015).

16 Various instrument lags are experimented and the decision to set this lag restriction is made because the estimation results fulfill the necessary requirements i.e., successfully pass the instrument's exogeneity (Hansen) and second order serial correlation (AR2) tests. 
sample is divided into three regime classes namely "always democracy", "always non-democracy", and countries that are "in-transition". The classification is made based on the preferred democracy variable IP2, and also according to the classification by ANRR, BMR, and CGV (recall data discussion).

\section{Results and Discussion}

\subsection{Baseline Results}

The analysis starts with the preliminary fixed effects estimation to determine the preferred model specification and its results are presented in Table 3 below. Overall, the estimation with either economic freedom (column 1) or democracy (2) as the only variable of interest, or both as the variables of interest (3), does not yield any significant individual effect on inequality. In column (4), both variables of interest are included together with their interaction, and now they are all statistically significant at the minimum conventional level 10\%. Economic freedom and democracy have positive association with inequality, while their interaction has negative. A preliminary interpretation of this finding points to a situation of inequality-increasing individual effect of economic freedom or democracy while holding other factors constant, but the negative coefficient for EFW*Democracy term may indicate a democratic regime's moderating effect on the freedom-induced inequality.

Table 3. Preliminary fixed effects estimations of various model specifications.

\begin{tabular}{|c|c|c|c|c|c|c|}
\hline & (1) & (2) & (3) & (4) & (5) & (6) \\
\hline Lagged Gini & & & & & & $\begin{array}{c}0.473^{* * *} \\
(0.051)\end{array}$ \\
\hline EFW & $\begin{array}{c}0.006 \\
(0.011) \\
\end{array}$ & & $\begin{array}{c}0.006 \\
(0.011) \\
\end{array}$ & $\begin{array}{l}0.036 * \\
(0.020)\end{array}$ & $\begin{array}{c}0.005 \\
(0.053) \\
\end{array}$ & $\begin{array}{l}0.027 * \\
(0.014)\end{array}$ \\
\hline Democracy & & $\begin{array}{c}0.041 \\
(0.033)\end{array}$ & $\begin{array}{c}0.025 \\
(0.032)\end{array}$ & $\begin{array}{c}0.209 * * \\
(0.099)\end{array}$ & $\begin{array}{c}0.225 * * \\
(0.099)\end{array}$ & $\begin{array}{l}0.130 * \\
(0.073)\end{array}$ \\
\hline EFW*Democracy & & & & $\begin{array}{c}-0.035 * \\
(0.020)\end{array}$ & $\begin{array}{c}-0.038 \text { * } \\
(0.020)\end{array}$ & $\begin{array}{c}-0.024 \text { * } \\
(0.014)\end{array}$ \\
\hline EFW squared & & & & & $\begin{array}{c}0.003 \\
(0.004)\end{array}$ & \\
\hline Observations & 463 & 483 & 463 & 463 & 463 & 463 \\
\hline Number of countries & 103 & 104 & 103 & 103 & 103 & 103 \\
\hline Adj. R-squared & 0.244 & 0.253 & 0.245 & 0.257 & 0.256 & 0.457 \\
\hline
\end{tabular}

Notes: Dependent variable is natural log of unbounded Gini of net income. A full set of control variables, and time and country dummies are included in the estimations but their results are not reported to conserve space. Economic freedom, democracy, education, real GDP per capita and real GDP per capita squared are lagged by one period to eliminate reverse causality issue. Standard errors are in parentheses and ${ }^{* * *}, * * * *$ indicates significant at $1 \%, 5 \%$, and $10 \%$ level.

In estimation (5) economic freedom squared is added into the model to account for its non-linear relationship to inequality but it is not significant. This inclusion has also caused economic freedom to lose its significance, although democracy and the interaction term are able to retain theirs. Due to its statistical insignificance, EFW squared is omitted from the model specification. Finally, lagged Gini is included in estimation (6) to account for the dynamics of the inequality. The result shows that lagged Gini coefficient is strongly significant at $1 \%$ and quantitatively larger than the other variables of interest. This indicates that Gini variable is persistent over time, and if it is omitted from the model the results would be biased. Both economic freedom and democracy and their interaction remain statistically significant at $10 \%$ level. Furthermore, the goodness of fit too improves compared to other estimations. Thus, estimation (6) is selected to be the preferred baseline model specification.

Table 4 below presents the estimated results of the preferred baseline specification modelling the relationship between economic freedom, democracy and income inequality. In addition to the overall freedom index EFW, the effects of individual areas of EFW, namely size of government (EFW1), legal 
system and property rights (EFW2), access to sound money (EFW3), freedom to trade internationally (EFW4), and regulation of credit, labor, and business (EFW5) are also estimated. Column 7-12 are fixed effects estimations while 13-18 are the Difference GMM estimations.

As is stated earlier, the reason the fixed effect estimation results are reported is to allow an appropriate comparison with previous studies using similar estimation method. Generally, the fixed effect results show that overall economic freedom index (EFW) and democracy are positively and significantly associated with inequality. The interaction of EFW*Democracy is negative significant implying a moderating effect of a democratic regime on the inequality-increasing effect of freedom. For the economic freedom areas, EFW2, EFW4 and EFW5 are significantly positively associated with inequality, but when they are interacted with democracy, only EFW4 and EFW5 retain their significance. The interaction terms for EFW4*Democracy and EFW5*Democracy mirror the estimation (7) with negative and significant coefficients.

Thus, the findings of positive significant overall freedom index (EFW), freedom to international trade (EFW4), and market deregulation (EFW5) are similar to that of Bergh and Nilsson (2010) and Bennett and Nikolaev (2016), but differ from Carter (2006) and Bennett and Vedder (2013) who find negative significant inequality-effect of economic freedom, and Sturm and Haan (2015) who find no relationship between freedom and inequality; all of these studies use fixed effects method.

Nevertheless, as is previously emphasized, Difference GMM is the preferred estimation method over fixed effects estimator since the former has econometric advantages over the latter. In discussing the Difference GMM estimated results, calculating the economic size of the effects, and making the plausible interpretation regarding the inequality-effects of economic freedom and democracy, the underlying theories and previously outlined hypotheses are used as a guide.

Referring to estimation 13, the overall economic freedom index and democracy are individually significant at $10 \%$ confidence level and positively associated with income inequality. The finding gives support to the hypothesis regarding the inequality-increasing effect of economic liberalization, but there is no support for the hypothesized income-equalizing effect of a democratic regime. The interaction between EFW*Democracy, albeit with the negative sign as is earlier hypothesized, is however not significant.

At this point, based on the insignificant interaction effect, ones may hastily infer that the inequality-effect of liberalization does not differ by regime types. The estimated results using the overall freedom index most likely to have obscured the true distributive effect of a certain aspect of economic freedom and the potential demarcated freedom effect that differs by regime types. These are only possible by digging deeper into the freedom-inequality links i.e., by taking into account different aspects of freedom and their interactions with democracy.

From the estimated results for each of the five areas of economic freedom, it is found that freedom to trade internationally EFW4 (column 17) and deregulation in credit, labor and business EFW5 (column 18) are significantly and positively associated with income inequality, both at $1 \%$ level, and stronger than the overall freedom index (EFW)'s significance of $10 \%$ (column 13).

Meanwhile, democracy variable too is positively associated with inequality and statistically significant at least $5 \%$ level albeit with lower size of coefficients than the democracy coefficient in overall estimation (column 13). Holding freedom to international trade and deregulation in credit, labor and business constant, democracy yields inequality-increasing effect, and not the income-equalizing effect as predicted in the theory and the hypothesis. Nevertheless, a caveat is necessary in interpreting this inequality-increasing effect of democracy, and it is explicitly discussed when the results are summarized at the end of this section.

Taking into account the freedom-democracy interaction, the effects of EFW4*Democracy and EFW5 ${ }^{*}$ Democracy are inequality-reducing as predicted and now they are significant at $10 \%$; a better result than the insignificant $\mathrm{EFW}^{*}$ Democracy interaction in column 13 . This finding thus strengthens the earlier hypothesis on the demarcated liberalization effect on inequality that differs according to regime types. From this finding too, it can be inferred that the accurate inequality-effect of a democracy 
is that it improves income distribution indirectly via economic freedom since it modifies the functioning of the market reform and liberalization policies such as freedom to international trade and deregulation policies - this will be discussed more in the results summary at the end of this section and in the policy implications in conclusion section. For EFW1-EFW3 (column 14-16), these areas of economic freedom are not significant at all, as do democracy variables and their interaction terms.

So far the results discussion is only on the sign and significance of the coefficients of economic freedom, democracy and their interactions. The coefficient sizes however cannot be interpreted linearly since the dependent variable is a nonlinear transformation of Gini. To assess the sizes of the inequality-effect of economic freedom, democracy and their interactions, which have been shown to be statistically significant in Table 4, the partial effect of the variables of interest and the corresponding partial derivative equation with the estimated coefficients in column 13, 17, and 18, (where EFW, EFW4 and EFW5 are significant respectively) are referred. Firstly, a baseline Gini value is computed by setting the variables of interest at their respective means. Then, 1 standard deviation above the means of the variables of interest is raised to see the changes in the Gini from its baseline value, and subsequently the size of change in the Gini values is determined. ${ }^{17}$

The calculation has resulted in the following findings: in absolute terms, and holding other variables constant, a rise in overall economic freedom index EFW by 1 standard deviation above its means increases Gini by $4.0 \%$ (from 63.44 to 65.95 ), a rise in freedom to trade internationally EFW4 by 1 standard deviation above its means increases Gini by 4.7\% (58.74 to 61.48), while a rise in deregulation of credit, labor and business market EFW5 by 1 standard deviation raises Gini by 3.9\% (62.18 to 64.63). For the democracy variable based on its estimated coefficients in model (13), (17), and (18), a 1 standard deviation rise in democracy above its means, holding other factors constant, raises Gini by $7.7 \%$ (57.69 to 62.11), 4.7\% (54.37 to 56.95), and 6.8\% (56.58 to 60.41) respectively. Finally, for the size of inequality-effect of economic freedom in a democratic regime, a rise of 1 standard deviation in EFW and democracy in estimation (13), in EFW4 and democracy in estimation (17), and in EFW5 and democracy in estimation (18), has resulted in a reduction in Gini by 5.9\% (57.01 to 53.67), $1.7 \%$ (55.36 to 54.40$)$, and $5.4 \%$ (56.27 to 53.21 ) respectively.

In the presence of lagged Gini among the right-hand-side regressors, the computed effects of economic freedom, democracy, and their interaction are considered as short-term effects. From Table 4, lagged Gini is statistically significant in the estimation in column 17 only with coefficient of 0.178 , but it is not in column 13 and 18. Therefore, the long term inequality-increasing effects of freedom to international trade EFW4 and democracy are 5.4\% and 5.6\%, respectively. For the interaction term EFW4*Democracy, the inequality-reducing effect over the long term is $2.1 \% .18$

Finally, as far as the empirical performance of Difference GMM estimation is concerned, it is reasonably satisfactory and robust. The test statistics for second-order serial correlation in the differenced residuals, AR2, show that it is unable to reject the null hypothesis of no serial correlation

17 Specifically, the calculations are as follows: (1) to determine the size of effect of economic freedom on inequality, we first set the baseline Gini value using this equation: $\ln \left[\right.$ Gini $/(100-$ Gini) $]=\beta_{2} e f w$ (based on the partial derivative $\partial g i n i / \partial e f w=\beta_{2}$ and holding other factors constant), then we raise 1 standard deviation in the efw variable above its mean, and recalculate the new Gini value to see the size of change in Gini from its baseline value, (2) to determine the size of effect of democracy on inequality, we set the baseline Gini value using this equation: $\ln \left[\right.$ Gini $/(100-$ Gini) $]=\beta_{3}$ dem (based on the partial derivative $\partial g \mathrm{ini} / \partial \mathrm{dem}=\beta_{3}$ and holding another factors constant), then we raise dem variable by 1 standard deviation above its mean, and recalculate the new Gini value to see the size of change in Gini from its baseline value, and finally (3) to determine the size of effect of economic freedom in a democratic regime, we set the baseline Gini value using this formula: $\ln [$ Gini $/(100-$ Gini $)]=\beta_{2} e f w+\beta_{4}(e f w * d e m)\left(\right.$ based on the partial derivative $\partial g i n i / \partial e f w=\beta_{2}+\beta_{4} d e m$ setting $\mathrm{dem}=1$ and holding other factors including individual dem constant), then we concurrently raise $e f w$ and $d e m$ by 1 standard deviation above their means, and recalculate the new Gini value to see the size of change in Gini from its baseline value. Please see also discussion on the partial effect the of variables of interest in Equation (2) in econometric specification section.

18 To obtain the long term effect, we first need to set gini $i_{\mathrm{it}}=$ gini $i_{\mathrm{it}-1}$ so that the dynamics in the dependent variable would converge to a new steady state level. Consequently, the long run effect of freedom to international trade EFW4 is given by: $\left[\beta_{2} / 1-\beta_{1}\right]$, long run effect of democracy is $\left[\beta_{3} / 1-\beta_{1}\right]$, and the long run effect of the interaction between EFW4*Democracy is $\left[\left(\beta_{2}+\beta_{4}\right.\right.$ dem $\left.) / 1-\beta_{1}\right]$, holding other variables constant. 
(with $p$-value of $0.19,0.32$ and 0.23 in estimation 13,17 , and 18 respectively). Similarly, the Hansen test for over-identification indicates the null hypothesis of overall instruments exogeneity is not rejected too (with $p$-value of $0.55,0.56$ and 0.48 in the three estimations respectively). The instrument count too is satisfactory at 82 which is well below the number of cross sectional unit of 95 (Roodman 2009).

\subsection{Summary of Baseline Results}

To summarize the baseline results, the estimated inequality-increasing effect of economic liberalization policy, either the overall freedom index, or the specific areas i.e., freedom to international trade and market deregulation policies, ranges between $\approx 4 \%-5 \%$ when they are implemented by a non-democratic regime. On the other hand, if these liberalization measures are implemented by a democratic regime, they are able to reduce the inequality by $\approx 2 \%-6 \%$. Finally, for a given level of economic freedom in the countries under study, a democratic regime is expected to cause an increase in inequality by $\approx 5 \%-8 \%$.

Recall in the empirical strategy, the instrument lag to achieve unbiased and consistent difference GMM estimators is set to $2-3$ periods. This means the (endogenous) variables of interest, i.e., economic freedom and democracy, are going to take ten to fifteen years to affect a corresponding change in the inequality level. Thus, the estimated $\approx 4 \%-5 \%$ inequality-increasing effect of economic freedom in a non-democratic regime is equivalent to a range of $0.27 \%-0.5 \%$ annually, the $\approx 2 \%-6 \%$ inequality-reducing effect of liberalization in a democratic regime is equivalent to $0.13 \%-0.6 \%$ annually, and the $\approx 5 \%-8 \%$ inequality-increasing effect of a democracy is equivalent to $0.33 \%-0.8 \%$ annually.

Overall, this study finds income-equalizing effect of economic liberalization policies when they are implemented by a democratic regime, or in other words, a democratic regime attenuates the freedom-induced inequality. This finding is indeed noteworthy and is apparently theoretically supported. Liberalization policies undoubtedly require necessary political support inasmuch that the presence of economic incentives and institutions is invariably determined by the political settings and constraints on executive in the country. As advocated by Acemoglu et al. (2005), economic development of a country is determined by economic institutions, and economic institutions in turn are shaped by the political interests of those in power.

In a non-democratic regime, freedom to international trade and market deregulation are shown to contribute to widening income inequality. However, both liberalization measures could have the intended positive effect on income distribution in the presence of a democratic regime.

This is particularly true since a democratic regime is expected to have no vested interests in its market deregulation and trade openness policies, thus eliminating the possibility of monopoly creation and rent-seeking practices. Similarly, a democratic country normally has expanded suffrage who are capable to elect and remove rulers and this in turn would ensure the government's decision making on liberalization policy would not be at the expense of the larger poor segments of population. A democratic regime too encourages political participation and gives rise to strong and organized labor unions with sufficient bargaining power to push for higher minimum wages, lower skill-based and technologically-influenced wage premiums, etc. In short, a democratic regime is expected have the capacity to improve income distribution and attenuate the freedom-induced inequality.

The finding of positive association between freedom to international trade and inequality too is theoretically reasonable. This finding is similar to other empirical studies such as Bergh and Nilsson (2010) and Meschi and Vivarelli (2009). In a country that has large trade activities with other countries, a widening income inequality between low-skilled and high-skilled labors is possible due to various factors such as skill premiums, technological differences, tariff differences, and many others. This finding therefore does not support the theoretical argument of Heckscher-Ohlin theory that openness to international trade decreases inequality. 
Likewise, the finding of significant inequality-increasing effect of market deregulation is also similar with the previous empirical findings, such as that of Calderón and Chong (2009) who find that labor market regulations reduce income inequality, and carries theoretical support. Deregulation in the market, although theoretically could provide more access to credit for the low income section of the population and may subsequently improve their earnings, could also cause adverse effect to them when the deregulation policies can be influenced by political elites to benefit a small section of the population.

On the other hand, the interpretation of inequality-increasing effect of democracy warrants an important caveat since the democracy indicator used in this study is a dichotomous score between 1 and 0 . As is earlier discussed, by using a dichotomous indicator, the main aim of the paper is to use the most convenient and straightforward segregation of the regime types between a democracy, an autocracy or a country in transition. This also conforms to the main focus of the paper which is on the demarcated distributive effect of economic freedom that is posited to vary according regime types, and not on the process of democratization. Granted, dichotomous indicator lacks detail on the degree of democratization in the countries which implies classifying together countries like Mongolia, Albania and Ecuador as having the same extent of democracy to United States, Canada and Germany.

Continuous democracy score meanwhile is inarguably able to reflect the process of democratization much better than a dichotomous democracy indicator. The former, therefore, is expected to give a more nuanced distinction between different countries which otherwise, if dichotomous score is used, would be simply classed together in a similar regime type. Thus, to casually infer that a democratic regime may increase a certain percentage of income inequality based on the results of a dichotomous democracy indicator may not be truly accurate. According to Doucouliagos and Ulubasoglu (2008), the estimated coefficients of this type of democracy variable may cause an upward bias, hence our little emphasis on this variable's results.

\subsection{Sensitivity Analysis}

In brief, the preceding baseline estimations find positive significant effects of EFW, EFW4, EFW5 and democracy variables, which signify the inequality-increasing effect of liberalization policies, specifically freedom to trade internationally and market deregulation, and democracy. Nevertheless, when these liberalization policies are implemented in a democratic regime, the results are reversed, i.e., their effects now are income-equalizing.

In this section, sensitivity analysis is conducted to test for the robustness of these baseline results. The sensitivity analysis is done by using alternative Gini variables (bounded Gini of net income, unbounded Gini of gross income, EHII Gini, all are in natural log), alternative democracy variables (ANRR, BMR, and CGV classification of democracy), by omitting several control variables from the baseline estimations, and by dividing the overall sample into sub-samples based on the income levels.

As is seen in Table 5 below, the sensitivity analysis in general shows that freedom to trade internationally EFW4 is the most consistently significant economic freedom variable in explaining the freedom-inequality relationship (EFW4 is significant in 10 out of total 11 alternative specifications). This is the case too for democracy variable and EFW $4{ }^{*}$ Democracy interaction term. Importantly, the signs of the variables of interest are identical to the baseline results. The estimated size of EFW4 coefficient ranges from $0.021-0.098$ with an average of 0.059 , and this average value is approximately similar to 0.055 in column 17 of the baseline results. Meanwhile, market deregulation EFW5 is also consistently significant in specifications using bounded Gini of net income, Gini of gross income, alternative democracy variables, and alternative set of controls as well as the high and upper middle income samples. As for the AR2 and Hansen tests, they are all unable to reject the null hypothesis in estimations where EFW4, EFW5, democracy and their interactions are significant. 
Several other interesting results are noteworthy. The results of estimations in column 19-30 for EFW index and its five sub-dimensions against bounded Gini of net income, and Gini of gross income are identical to the baseline results especially in estimation using EFW index, EFW4, and EFW5 (Panel A, E and F). This is not surprising since both Gini of net income and gross income are from the same dataset. In estimation (31-36), another alternative inequality variable namely Gini index of the Estimated Household Income Inequality (EHII) obtained from University of Texas Inequality Project is used. This dataset, which is available up to 2008 only and with smaller number of observations (227) and countries (73), has resulted in inconsistent findings as far as the overall EFW index and EFW5 are concerned. Nevertheless, the signs of the variable of interest are identical to baseline estimations. Meanwhile, using alternative democracy variables does not yield any significant variation to the baseline results. However, as is seen in Panel A estimations in column 37-48, the coefficients of EFW index interacted with democracy variable from ANRR and BMR are now statistically significant. On the other hand, when using CGV democracy variable, the interaction is not significant similar to the baseline result in column 13 .

The baseline estimation includes a number of control variables capturing the effect of education, real GDP per capita, its squared value, age dependency ratio, urban population, employment industrial sector and employment in service sector. Although their results are not in the interest of the study, their inclusion is crucial to estimate the accurate effects of the variables of interest. Omission of certain control variables may cause an omitted variable bias which means the inequality-effects of the omitted variables might have been picked up by the included variables (including the variables of interest) thereby resulting in an over- or under-estimation of the effect of the variables of interest. The baseline estimation thus begins with the most general specification that includes a full set of control variables, and in the sensitivity analysis, a number of control variables are omitted progressively.

In estimations in column 55-60 of Table 5, the first alternative set of control variables (Set 1) is used. This set comprises of education, real GDP per capita and real GDP per capita squared only, and omits age dependency ratio, urban population, employment in industrial sector and in service sector. In estimations in column 61-66, Set 2 control variables is used, consisting of education, real GDP per capita, its squared value, age dependency ratio and urban population, and omitting employment in industrial sector and in service sector. The results are almost identical to our baseline estimation in which the overall EFW index, EFW4, democracy and the interaction terms are consistently significant with expected sign. In estimation with EFW5 (Panel F), only EFW5 is consistently positive significant, but democracy and the interaction term are not. Note the improving number of observations (to more than 450) and countries (to 106/107) when we use different sets of control variables as compared to the baseline estimation (13) in Table 5 (368 and 95 respectively).

Finally, the sensitivity analysis seeks to ascertain the significant effect of economic freedom and democracy on inequality across different level of economic development. To do so, the sample countries are initially divided into two sub-samples namely high income (42 countries) and middle income (which comprises of upper middle income-31 countries, and lower middle income-26 countries). This division however may not be thoroughly accurate due to its substantial cross-country income heterogeneity especially in the middle income group that clusters together countries in the upper level with the lower level of the middle income range. Consequently, two more sub-samples are created, one clusters together high income and upper middle income countries, while the other low and lower middle income countries. This clustering makes the newly added two sub-samples seemingly homogenous as far as the income range is concerned. ${ }^{19}$

19 According to the latest classification by the World Bank, a middle income country is an economy whose Gross National Income (GNI) between $\$ 1026-12475$ threshold; with lower middle income GNI between $\$ 1026-\$ 4035$, and upper middle income GNI between $\$ 4036-\$ 12,475$. Note the skewed range of GNI for the upper middle income group. The range of GNI between $\$ 0-\$ 1025$ for low income group is thus naturally closer to the lower middle income group GNI range. 
The results show that overall freedom index and democracy variables are strongly significant and positively associated with inequality in high and upper middle income countries (Panel A estimation 79-84). Compared to the baseline results in estimation (13), the size of the coefficients is apparently larger with stronger level of confidence. This shows that the baseline results are highly likely driven by the developed countries. Note the sample countries "high and upper middle income" of 66 constitutes about $70 \%$ of the total 95 countries in the baseline estimation, and of the 66,39 are high income countries. This is not unexpected since this group of countries is normally assumed to have stronger level of democracy and greater freedom. As for the EFW areas, freedom to international trade EFW4 retains the similar finding as in the baseline estimation (17). Market deregulation EFW5 meanwhile only yields a positive significant effect for its own coefficient and so does democracy individually, while their interaction is not significant, albeit with the predicted sign.

\subsection{Economic Freedom-Inequality Relationship in Different Regimes}

This section seeks to demarcate the effect of liberalization on inequality according to regime types. Equation (1) is re-estimated on several groups of countries classified as "always democracy", "always non-democracy", and "in-transition" as earlier discussed in the data section. Now, the classification is based not only on the preferred democracy variable IP2 but also on the alternative variables ANRR, BMR, and CGV. Note that the classification of democracy slightly differs between IP2, ANRR, BMR and CGV, hence the differing number of countries for the three regime types "always democracy", "always non-democracy", and "in-transition" for each of the four data sources.

Table 6 presents the Difference GMM estimation of Equation (1) without the democracy variable $\mathrm{dem}$ and the interaction term from the model. ${ }^{20}$ The main objective is to test for the sensitivity of the baseline results as far as the economic freedom effect on inequality is concerned. The results clearly show the significance of freedom of international trade EFW4 variable and its positive association with inequality in both democratic and in-transition country samples (Panel E of Table 6). However, in the non-democratic country sample, the freedom variable is not significant with conflicting signs (note the significantly lower number of observations in non-democracy sample which is thought as the likely reason behind the poor results). The estimations with significant EFW4 variable also fulfill the requirements of no second order serial correlation and overall instrument exogeneity as indicated by the test statistics of AR2 and Hansen tests, respectively.

To determine the size of effect of economic freedom on inequality according to different regimes, the calculation (1) in Footnote 16 is repeated. In the sample of democratic countries, it is found that a rise in freedom to trade internationally EFW 4 by 1 standard deviation above its means increases Gini by $2.4 \%$ (55.96 to 57.31 ), whereas in the sample of in-transition countries, the size of change in Gini coefficient is $3.5 \%$ (55.41 to 57.35$){ }^{21}$

The different sizes of inequality-increasing effect of freedom underscore an important distinction between the democratic and in-transition countries and strengthen our baseline finding that democracy attenuates the freedom-induced inequality. The finding shows that always democratic countries, i.e., countries that democratize earlier and stay in democracy for a long period of times are often characterized with greater democratic stock (such as improved political freedom and rights, increased political participation, and expanded suffrage as well as greater unionization), are presumably capable to check the inequality-increasing effect of liberalization.

20 By omitting dem variable we are assuming the effect of regime types are fully captured by the country fixed effects term.

21 This is an average effect, since the average values for the coefficient, the mean, and the standard deviation of EFW4 variable are used since there are four sources for democracy classification. Specifically, for each regime type, the average of the four means and standard deviations are obtained from the variable's summary statistics according to four difference democracy sources. Similarly, the average of the EFW4 coefficients used is the one reported in Table 6 according to regime classification based on the four different democracy sources. 
Table 4. Baseline FE and Difference GMM estimations of the effects of economic freedom and democracy on income inequality.

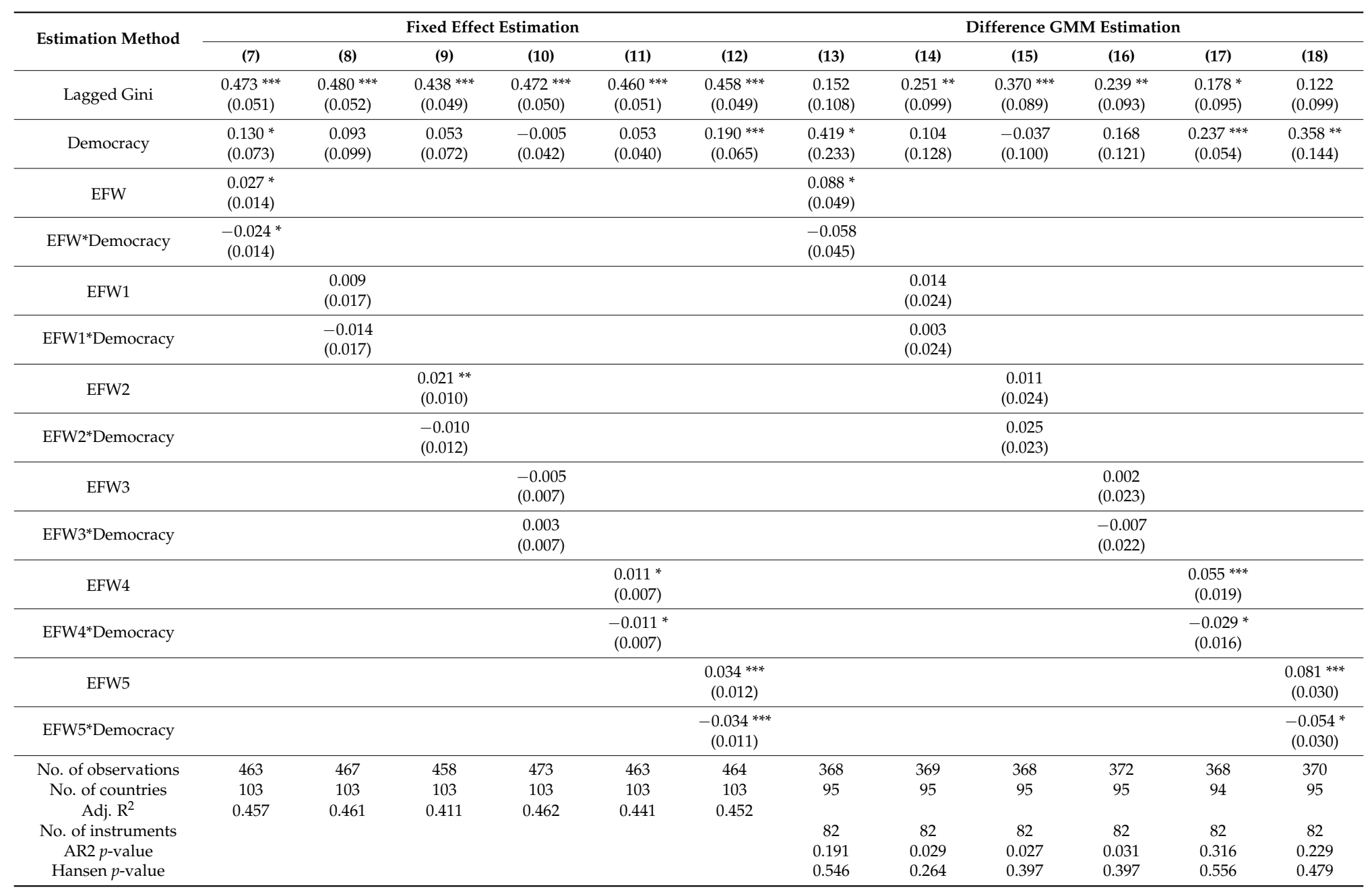

Notes: Dependent variable is natural log of unbounded Gini of net income. A full set of control variables is included in the estimation, however their results are not reported to conserve space, so are the constants. AR2 tests for second order autocorrelation in the differenced error term, with null hypothesis of no autocorrelation. Hansen tests for the instruments' exogeneity with a null hypothesis of the overall instruments as a group are exogenous. Standard errors are in parentheses and ${ }^{* * *}, * * *$ indicates $1 \%, 5 \%$ and $10 \%$ significance level. 
Table 5. Difference GMM estimations with alternative variables, model specifications, and level of development.

\begin{tabular}{|c|c|c|c|c|c|c|c|c|c|c|c|c|c|}
\hline & & \multicolumn{3}{|c|}{ 1. Alternative Gini } & \multicolumn{3}{|c|}{ 2. Alternative Democracy Variable } & \multicolumn{2}{|c|}{ 3.Control Variables } & \multicolumn{4}{|c|}{ 4. Level of Development } \\
\hline & & $\begin{array}{l}\text { Gini Net } \\
\text { (Bounded) }\end{array}$ & $\begin{array}{c}\text { Gini } \\
\text { Gross }\end{array}$ & $\begin{array}{l}\text { EHII } \\
\text { Gini }\end{array}$ & ANRR & BMR & CGV & Set 1 & Set 2 & High Income & Middle Income & HI \& Upper MI & LI \& Lower MI \\
\hline & Estimation & $(19-24)$ & $(25-30)$ & $(31-36)$ & $(37-42)$ & $(43-48)$ & $(49-54)$ & $(55-60)$ & $(61-66)$ & $(67-72)$ & (73-78) & $(79-84)$ & $(85-90)$ \\
\hline \multirow{5}{*}{ A } & EFW & $0.058^{* *}$ & $0.115 *$ & 0.006 & $0.162 * *$ & $0.100 * * *$ & $0.072^{* * *}$ & $0.095 * *$ & $0.108 * * *$ & 0.074 & -0.001 & $0.120^{* * *}$ & 0.020 \\
\hline & Democracy & $0.266^{*}$ & $0.561^{*}$ & 0.173 & $0.717^{* *}$ & $0.434^{* * *}$ & $0.270^{*}$ & $0.427^{*}$ & $0.433^{* *}$ & 0.278 & 0.000 & $0.541^{* * *}$ & -0.142 \\
\hline & EFW*Democracy & -0.037 & -0.083 & -0.018 & -0.124 * & $-0.073 * *$ & -0.040 & $-0.076^{*}$ & $-0.084^{* *}$ & -0.047 & 0.018 & $-0.095^{* * *}$ & 0.028 \\
\hline & AR2 $p$-value & 0.126 & 0.534 & 0.568 & 0.250 & 0.100 & 0.100 & 0.046 & 0.034 & 0.007 & 0.724 & 0.053 & 0.520 \\
\hline & Hansen $p$-value & 0.495 & 0.461 & 0.250 & 0.275 & 0.487 & 0.531 & 0.386 & 0.307 & 1.000 & 0.997 & 0.902 & 1.000 \\
\hline \multirow{5}{*}{ B } & EFW 1 & -0.010 & 0.031 & -0.005 & 0.008 & $0.033 * *$ & 0.031 * & $0.045^{*}$ & $0.050^{* *}$ & -0.012 & -0.001 & -0.016 & -0.030 \\
\hline & Democracy & 0.016 & 0.310 * & $0.137^{*}$ & 0.075 & $0.202 *$ & 0.162 & $0.362 * *$ & $0.390^{* * *}$ & 0.045 & 0.056 & 0.010 & -0.141 \\
\hline & EFW1*Democracy & 0.015 & -0.031 & -0.011 & 0.005 & -0.021 & -0.013 & $-0.053^{* *}$ & $-0.060 * *$ & 0.007 & 0.003 & 0.022 & 0.028 \\
\hline & AR2 $p$-value & 0.054 & 0.413 & 0.509 & 0.025 & 0.046 & 0.044 & 0.017 & 0.012 & 0.010 & 0.792 & 0.027 & 0.198 \\
\hline & Hansen $p$-value & 0.201 & 0.215 & 0.419 & 0.299 & 0.316 & 0.210 & 0.296 & 0.234 & 1.000 & 0.999 & 0.762 & 1.000 \\
\hline \multirow{5}{*}{ C } & EFW2 & -0.002 & -0.032 & $-0.033^{* *}$ & 0.015 & 0.022 & 0.020 & 0.000 & 0.010 & 0.006 & 0.010 & -0.038 & 0.017 \\
\hline & Democracy & -0.051 & -0.172 & -0.025 & -0.024 & 0.015 & 0.029 & -0.130 & -0.095 & -0.191 & 0.114 & -0.265 & -0.107 \\
\hline & EFW2*Democracy & $0.024 *$ & 0.064 * & $0.025 *$ & 0.019 & 0.012 & 0.014 & $0.038^{*}$ & 0.030 & 0.037 & -0.005 & $0.066^{* *}$ & 0.028 \\
\hline & AR2 $p$-value & 0.023 & 0.523 & 0.662 & 0.025 & 0.025 & 0.033 & 0.081 & 0.085 & 0.002 & 0.634 & 0.017 & 0.627 \\
\hline & Hansen $p$-value & 0.331 & 0.465 & 0.392 & 0.319 & 0.536 & 0.450 & 0.245 & 0.231 & 1.000 & 0.998 & 0.948 & 1.000 \\
\hline \multirow{5}{*}{ D } & EFW3 & -0.012 & -0.013 & -0.006 & 0.015 & -0.001 & -0.009 & -0.010 & -0.009 & -0.031 & -0.009 & 0.013 & 0.002 \\
\hline & Democracy & 0.035 & 0.089 & 0.096 & $0.228 * *$ & 0.099 & 0.076 & 0.103 & 0.086 & -0.084 & $0.067^{* *}$ & $0.163^{*}$ & -0.021 \\
\hline & EFW3*Democracy & 0.012 & 0.012 & 0.001 & -0.021 & -0.002 & 0.007 & 0.003 & 0.003 & 0.027 & 0.005 & -0.015 & 0.005 \\
\hline & AR2 $p$-value & 0.033 & 0.483 & 0.947 & 0.020 & 0.018 & 0.022 & 0.015 & 0.020 & 0.003 & 0.697 & 0.010 & 0.343 \\
\hline & Hansen $p$-value & 0.414 & 0.446 & 0.272 & 0.407 & 0.364 & 0.423 & 0.223 & 0.272 & 1.000 & 0.997 & 0.903 & 1.000 \\
\hline \multirow{5}{*}{ E } & EFW4 & $0.036 *$ & $0.081^{* * * *}$ & $0.021 *$ & $0.067^{* * *}$ & $0.062 * * *$ & $0.063^{* * *}$ & $0.060^{* * *}$ & $0.080 * * *$ & $0.098^{*}$ & $0.032 * *$ & $0.057^{* *}$ & 0.038 \\
\hline & Democracy & $0.163^{* * *}$ & $0.352 * * *$ & $0.166^{* * *}$ & $0.252 * * *$ & $0.252 * * *$ & $0.242^{* * *}$ & $0.175 *$ & $0.224 * * *$ & 0.264 & $0.128 *$ & $0.230^{* * *}$ & -0.024 \\
\hline & EFW4*Democracy & -0.021 & $-0.050 *$ & -0.019 * & $-0.042^{* *}$ & $-0.039^{* * *}$ & $-0.038^{* * *}$ & $-0.039 *$ & $-0.054^{* * *}$ & -0.076 & -0.008 & $-0.038^{*}$ & 0.012 \\
\hline & AR2 $p$-value & 0.239 & 0.776 & 0.279 & 0.315 & 0.339 & 0.149 & 0.088 & 0.099 & 0.026 & 0.488 & 0.136 & 0.562 \\
\hline & Hansen $p$-value & 0.683 & 0.491 & 0.328 & 0.368 & 0.585 & 0.588 & 0.447 & 0.681 & 1.000 & 0.996 & 0.861 & 1.000 \\
\hline \multirow{5}{*}{$\mathrm{F}$} & EFW5 & $0.047^{* *}$ & $0.150^{* * *}$ & 0.028 & $0.113^{* * *}$ & $0.094^{* * *}$ & $0.079^{* * *}$ & $0.063^{* *}$ & $0.061 * *$ & 0.002 & 0.019 & $0.050 *$ & -0.053 \\
\hline & Democracy & $0.236^{* *}$ & $0.715^{* * *}$ & $0.207^{* * *}$ & $0.469^{* * *}$ & $0.419 * *$ & $0.328^{* *}$ & $0.297^{*}$ & 0.264 & 0.080 & 0.124 & 0.263 ** & -0.040 \\
\hline & EFW5*Democracy & -0.035 * & $-0.125^{* * *}$ & -0.031 * & $-0.084^{* *}$ & $-0.075^{* *}$ & $-0.054^{*}$ & -0.054 & -0.050 & 0.008 & -0.012 & -0.038 & 0.012 \\
\hline & AR2 $p$-value & 0.190 & 0.696 & 0.544 & 0.241 & 0.128 & 0.250 & 0.015 & 0.013 & 0.011 & 0.756 & 0.147 & 0.105 \\
\hline & Hansen $p$-value & 0.418 & 0.464 & 0.417 & 0.330 & 0.248 & 0.348 & 0.446 & 0.380 & 1.000 & 0.997 & 0.856 & 1.000 \\
\hline \multirow{3}{*}{\multicolumn{2}{|c|}{$\begin{array}{l}\text { No. of observations } \\
\text { No. of countries } \\
\text { No. of instruments }\end{array}$}} & $368-372$ & $368-372$ & $226-227$ & $368-372$ & $368-372$ & $368-372$ & $466-483$ & $456-473$ & 184-187 & $172-173$ & $288-292$ & $79-80$ \\
\hline & & 95 & 95 & 73 & 95 & 95 & 95 & 107 & 106 & 39 & 48 & 66 & 29 \\
\hline & & 82 & 82 & 69 & 82 & 82 & 82 & 85 & 87 & 80 & 79 & 82 & 61 \\
\hline
\end{tabular}

Notes: See notes in Table 4 for more details of estimation. Panel A-F represent six separate estimations for overall EFW and its five areas, respectively. Estimation 25-30 use EHII Gini index as dependent variable. Baseline democracy variable IP2 is used in all estimations except in estimation 31-36, 37-42 and 43-48. Estimation 19-48 and 61-84 include all control variables. Estimation 49-54 include Set 1 control variables comprises of education, real GDP per capita, and real GDP per capita squared, while estimation 55-60 include Set 2 control variables which omits employment in service and in industry. Standard errors are not reported to conserve space. ${ }^{* * *}, * *, *$ indicates $1 \%, 5 \%$ and $10 \%$ significance level. 
Table 6. Difference GMM estimations of economic freedom-inequality relationship in different regime types.

\begin{tabular}{|c|c|c|c|c|c|c|c|c|c|c|c|c|c|}
\hline & & \multicolumn{4}{|c|}{ 1. Always Democracy } & \multicolumn{4}{|c|}{ 2. In Transition } & \multicolumn{4}{|c|}{ 3. Always Non-Democracy } \\
\hline & & IP2 & ANRR & BMR & CGV & IP2 & ANRR & BMR & CGV & IP2 & ANRR & BMR & CGV \\
\hline & Estimation & $(91-96)$ & $(97-102)$ & $(103-108)$ & $(109-114)$ & $(115-120)$ & $(121-126)$ & $(127-132)$ & $(133-138)$ & $(139-144)$ & $(145-150)$ & $(151-156)$ & $(157-162)$ \\
\hline \multirow{4}{*}{ A } & EFW & $0.035 *$ & $0.038^{*}$ & 0.030 & 0.026 & 0.006 & -0.003 & 0.013 & 0.001 & -0.064 & 0.065 & 0.036 & 0.032 \\
\hline & & $(0.019)$ & $(0.020)$ & $(0.022)$ & $(0.018)$ & $(0.030)$ & $(0.028)$ & $(0.028)$ & $(0.028)$ & $(0.204)$ & $(0.211)$ & $(0.085)$ & $(0.051)$ \\
\hline & AR2 $p$-value & 0.059 & 0.070 & 0.053 & 0.031 & 0.106 & 0.120 & 0.220 & 0.217 & - & 0.538 & 0.668 & 0.073 \\
\hline & Hansen $p$-value & 0.870 & 0.783 & 0.954 & 0.907 & 0.998 & 0.997 & 0.980 & 1.000 & 1.000 & 1.000 & 1.000 & 1.000 \\
\hline \multirow{4}{*}{ B } & EFW1 & 0.013 & 0.013 & 0.008 & 0.020 & -0.011 & -0.015 & -0.011 & -0.008 & -0.049 & -0.074 & -0.023 & -0.038 \\
\hline & & $(0.014)$ & $(0.013)$ & $(0.018)$ & $(0.015)$ & $(0.020)$ & $(0.021)$ & $(0.024)$ & $(0.022)$ & $(0.191)$ & $(0.127)$ & $(0.049)$ & $(0.057)$ \\
\hline & AR2 $p$-value & 0.039 & 0.049 & 0.048 & 0.013 & 0.208 & 0.269 & 0.340 & 0.243 & 0.114 & 0.373 & 0.839 & 0.931 \\
\hline & Hansen $p$-value & 0.818 & 0.756 & 0.897 & 0.713 & 0.997 & 0.997 & 0.985 & 1.000 & 1.000 & 1.000 & 0.999 & 0.999 \\
\hline \multirow{4}{*}{ C } & EFW2 & $0.028 *$ & $0.026^{*}$ & 0.013 & 0.015 & 0.023 & 0.022 & $0.028 *$ & $0.026^{*}$ & -0.047 & -0.012 & 0.009 & 0.009 \\
\hline & & $(0.014)$ & $(0.014)$ & $(0.008)$ & $(0.012)$ & $(0.015)$ & $(0.014)$ & $(0.014)$ & $(0.015)$ & $(0.049)$ & $(0.083)$ & $(0.044)$ & $(0.029)$ \\
\hline & AR2 $p$-value & 0.028 & 0.029 & 0.033 & 0.013 & 0.143 & 0.118 & 0.194 & 0.186 & 0.717 & 0.787 & 0.720 & 0.998 \\
\hline & Hansen $p$-value & 0.779 & 0.820 & 0.969 & 0.860 & 0.993 & 0.998 & 0.990 & 1.000 & 1.000 & 1.000 & 1.000 & 1.000 \\
\hline \multirow{4}{*}{$\mathrm{D}$} & EFW3 & 0.006 & 0.010 & 0.003 & 0.006 & -0.012 & -0.011 & -0.013 & -0.010 & 0.028 & 0.029 & 0.009 & -0.014 \\
\hline & & $(0.009)$ & $(0.008)$ & $(0.010)$ & $(0.011)$ & $(0.007)$ & $(0.007)$ & $(0.009)$ & $(0.007)$ & $(0.071)$ & $(0.056)$ & $(0.028)$ & $(0.017)$ \\
\hline & AR2 $p$-value & 0.037 & 0.039 & 0.017 & 0.011 & 0.150 & 0.134 & 0.179 & 0.196 & 0.482 & 0.533 & 0.554 & 0.177 \\
\hline & Hansen $p$-value & 0.778 & 0.714 & 0.900 & 0.844 & 0.991 & 0.996 & 0.990 & 0.999 & 1.000 & 1.000 & 1.000 & 1.000 \\
\hline \multirow{4}{*}{$\mathrm{E}$} & EFW4 & $0.036^{* * *}$ & $0.039^{* * *}$ & $0.028^{* * *}$ & $0.028^{* * *}$ & $0.039^{* * *}$ & $0.040^{* * *}$ & $0.037^{* * *}$ & $0.035^{* *}$ & -0.011 & 0.022 & 0.017 & 0.049 \\
\hline & & $(0.011)$ & $(0.012)$ & $(0.010)$ & $(0.010)$ & $(0.013)$ & $(0.012)$ & $(0.011)$ & $(0.015)$ & $(0.078)$ & $(0.100)$ & $(0.032)$ & $(0.045)$ \\
\hline & AR2 $p$-value & 0.100 & 0.100 & 0.055 & 0.036 & 0.276 & 0.368 & 0.303 & 0.435 & 0.478 & 0.798 & 0.438 & 0.296 \\
\hline & Hansen $p$-value & 0.728 & 0.739 & 0.925 & 0.926 & 0.999 & 1.000 & 0.999 & 1.000 & 1.000 & 0.999 & 0.999 & 1.000 \\
\hline \multirow{4}{*}{$\mathrm{F}$} & EFW5 & 0.010 & 0.011 & 0.016 & 0.017 & 0.030 & 0.022 & 0.008 & 0.028 & -0.032 & -0.003 & 0.009 & 0.025 \\
\hline & & $(0.016)$ & $(0.017)$ & $(0.020)$ & $(0.016)$ & $(0.026)$ & $(0.023)$ & $(0.023)$ & $(0.023)$ & $(0.139)$ & $(0.169)$ & $(0.043)$ & $(0.015)$ \\
\hline & AR2 $p$-value & 0.067 & 0.064 & 0.053 & 0.023 & 0.255 & 0.299 & 0.308 & 0.273 & 0.994 & 0.906 & 0.770 & 0.076 \\
\hline & Hansen $p$-value & 0.641 & 0.842 & 0.967 & 0.920 & 0.986 & 0.996 & 0.980 & 1.000 & 1.000 & 1.000 & 1.000 & 1.000 \\
\hline \multirow{3}{*}{\multicolumn{2}{|c|}{$\begin{array}{l}\text { No. of observations } \\
\text { No. of countries } \\
\text { No. of instruments }\end{array}$}} & 198-201 & 200-203 & $178-180$ & 188-191 & $141-143$ & $137-140$ & $145-148$ & $130-132$ & 27 & 29 & 43 & $47-49$ \\
\hline & & 49 & 50 & 44 & 47 & 35 & 33 & 34 & 29 & 11 & 12 & 17 & 19 \\
\hline & & 58 & 58 & 58 & 58 & 58 & 58 & 58 & 58 & 27 & 29 & 40 & 42 \\
\hline
\end{tabular}

indicates significant at $1 \%, 5 \%$ and $10 \%$ respectively. 


\section{Conclusions and Policy Implications}

This paper revisits the interlinkage of economic liberalization, democracy and income inequality with the main objective to uncover the role of a political regime in the economic freedom-inequality nexus. Ambiguous findings in the previous studies either on the relationship of economic freedom-inequality or democracy-inequality leave policymakers, development agencies and other stakeholders with little guidance on the potential distributive effects resulting from liberalization policies or a regime choice a country make undertake.

To achieve this objective, an inequality model that explicitly captures the interaction effect of economic freedom and democracy is estimated to determine the distributive effect of economic liberalization policy, and this effect is posited to differ according to regime types. This study utilizes the latest inequality data from SWIID version 5.0, which is superior in term of its comparability and reliability than the other inequality datasets, for up to 115 countries for 45 -year period together with democracy classification from four different sources.

The estimated results find liberalization, either the overall freedom index or specifically the freedom to international trade and market deregulation, has robust positive relationship with inequality. The estimated size of inequality-increasing effects of economic freedom is substantial ranging between $0.3-0.6 \%$ per annum for every 1 standard deviation rise in the means of the variable. For a given level of economic freedom, a democratic regime too has positive effect on inequality although the interpretation needs a caveat due to the type of democracy indicator used in the study. On the other hand, the results show a statistically significant negative interaction effect of economic freedom-democracy, indicating that the freedom-induced inequality is lower in the presence of a democratic regime.

In short, the study is able to meet its main objective to uncover the distinctive inequality-effect of liberalization that differs according to regime types. The results yield a robust evidence that the inequality-increasing impacts of liberalization policies, such as freedom of international trade and market deregulation, are attenuated when these policies are implemented by a democratic regime. This finding is crucial for policymakers to decide on their liberalization strategies that may necessitate the free market policy reform to be embedded in a democratic environment due to the significant different redistributive effect when the similar policy reform is implemented in the countries that are relatively less democratic.

Market-based economic reform is generally expected to create an environment conducive for expanded trade and investment, increased business exchanges within and across borders, as well as less-restraint exchanges in credit, labor and product markets. These favorable environments are eventually expected to result in higher economic growth for the country generally and specifically greater government tax base and revenues.

Therefore, the findings of this paper propose that a democratic government has the capacity to sustain and extend the positive benefits of these market reforms across a wider segment of population via various egalitarian redistributive measures such as welfare-augmenting transfers, increased child benefits and healthcare, better access education, and other income-equalizing measures. A democratic regime too is expected to be more transparent and accountable in its implementation of the reform policies eliminating the potential rent-seeking practices and captured interests from the richer segment of the population.

Nevertheless, this study is not without its limitation, particularly with the use of dichotomous democracy score. Although it provides a convenient way to segregate the countries according to their regime types, dichotomous score however lacks details on the degree of democratization and consequently prevents better empirical findings to be attained such as that of with a more distinctive threshold level in the distributive-effect of democracy. Future studies on the inequality-democracy-liberalization relationship may consider this aspect of democracy threshold analysis as it is expected to yield an important insight into the necessary level of democratization a country must attain in order to mitigate the inequality-increasing effect of economic liberalization. 
Acknowledgments: The author gratefully acknowledges the funding from the Ministry of Higher Education, Malaysia for the author's academic visit to University of Cambridge, United Kingdom (08/2015-07/2017).

Conflicts of Interest: The author declares no conflict of interest.

\section{Appendix A}

Table A1. Summary statistics and sources the variables.

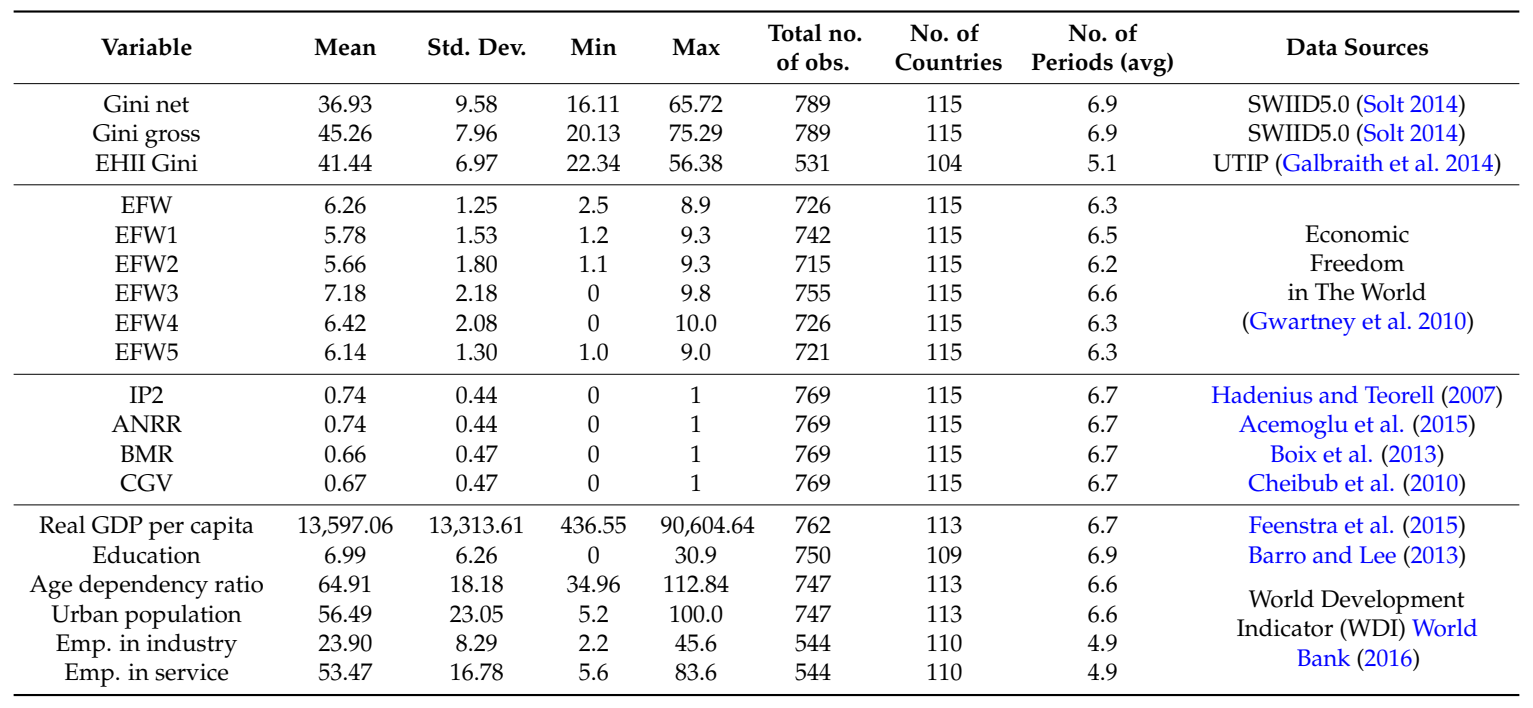

Table A2. Pairwise correlation matrix.

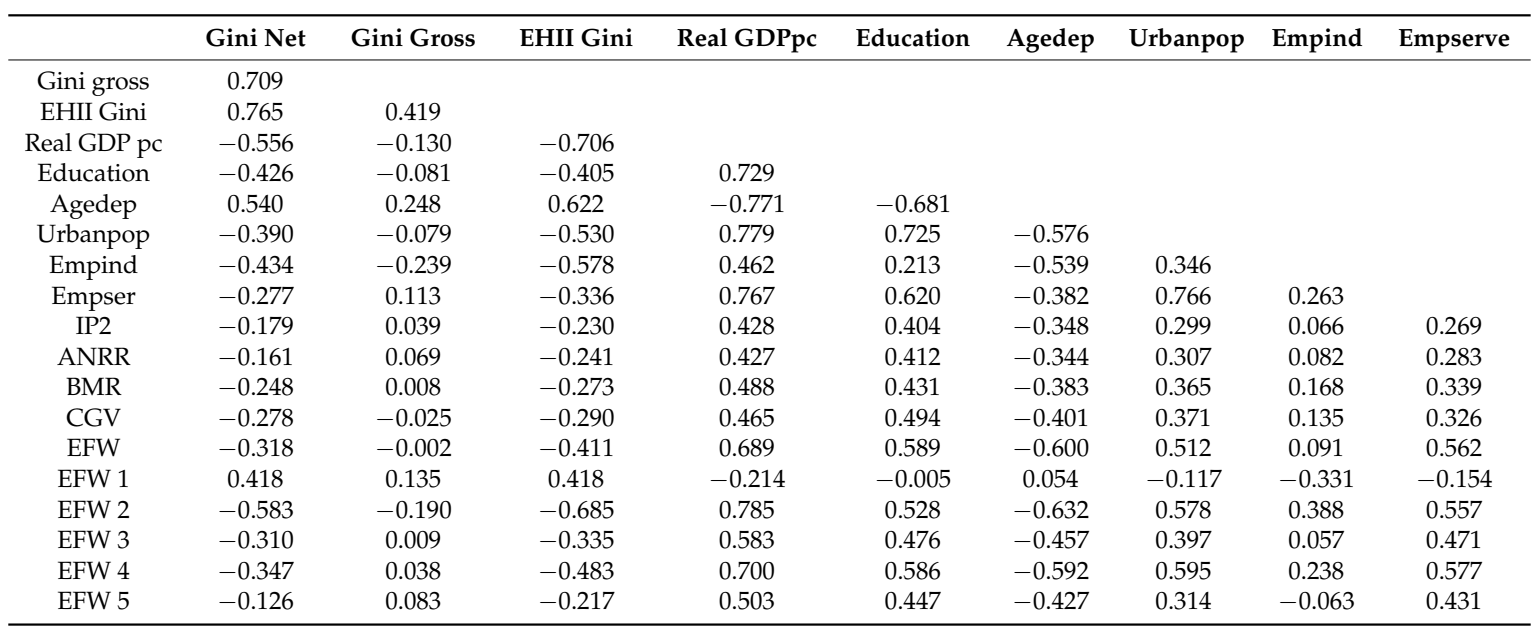


Table A3. The Economic Freedom in the World Index-the five areas.

1: $\quad$ Size of government: expenditures, taxes, and enterprises (EFW1)

A. General government consumption spending as a percentage of total consumption

B. Transfers and subsidies as a percentage of GDP

C. Government enterprises and investment as a percentage of GDP

D. Top marginal tax rate (and income threshold at which it applies)

i. Top marginal income tax rate (and income threshold at which it applies)

ii. Top marginal income and payroll tax rate (and income threshold at which it applies)

2: $\quad$ Legal structure and security of property rights (EFW2)

A. Judicial independence: the judiciary is independent and not subject to interference from the government or parties in disputes

B. Impartial courts: a trusted legal framework exists for private businesses to challenge the legality of government actions or regulation

C. Protection of intellectual property

D. Military interference in rule of law and the political process

E. Integrity of the legal system

3: $\quad$ Access to sound money (EFW3)

A. Average annual growth of the money supply in the last five years minus average annual growth of real GDP in the last ten years

B. Standard inflation variability in the last five years

C. Recent inflation rate

D. Freedom to own foreign currency bank accounts domestically and abroad

4: $\quad$ Freedom to trade internationally (EFW4)

A. Taxes on international trade

i. Revenue from taxes on international trade as a percentage of exports plus imports

ii. Mean tariff rate

iii. Standard deviation of tariff rates

B. Regulatory trade barriers

i. Hidden import barriers: no barriers other than published tariffs and quotas

ii. Costs of importing: the combined effect of import tariffs, license fees, bank fees, and the time required for

administrative red tape raises costs of importing equipment: by $10 \%$ or less $=10$, by more than $50 \%=0$

C. Actual size of trade sector compared with expected size

D. Difference between official exchange rate and black market rate

E. International capital market controls

i. Access of citizens to foreign capital markets and foreign access to domestic capital markets

ii. Restrictions on the freedom of citizens to engage in capital market exchange with foreigners-index of capital controls among 13 IMF categories

5: $\quad$ Regulation of credit, labor, and business (EFW5)

A. Credit market regulations

i. Ownership of banks: percentage of deposits held in privately owned banks

ii. Competition: domestic banks face competition from foreign banks

iii. Extension of credit: percentage of credit extended to private sector

iv. Avoidance of interest rate controls and regulations that lead to negative real interest rates

v. Interest rate controls: interest rate controls on bank deposits and/or loans are freely determined by the market

B. Labor market regulations

i. Impact of minimum wage: the minimum wage, set by law, has little impact on wages because it is too low or not obeyed

ii. Hiring and firing practices: hiring and firing practices of companies are determined by private contract

iii. Share of labor force whose wages are set by centralized collective bargaining

iv. Unemployment benefits: the unemployment benefits system preserves the incentive to work

v. Use of conscripts to obtain military personnel

C. Business regulations

i. $\quad$ Price controls: extent to which businesses are free to set their own prices

ii. Administrative conditions and new businesses: administrative procedures are an important obstacle to starting a new business

iii. Time spent dealing with government bureaucracy: senior management spends a substantial amount of time dealing with government bureaucracy

iv. Starting a new business: starting a new business is generally easy

v. Irregular payments: irregular, additional payments connected with import and export permits, business licenses, exchange controls, tax assessments, police protection, or loan applications are very rare 
Table A4. List of countries based on income level (World Bank classification).

\begin{tabular}{|c|c|c|c|}
\hline $\begin{array}{l}\text { High Income } \\
\text { (42 Countries) }\end{array}$ & $\begin{array}{l}\text { Upper Middle Income } \\
\text { (31 Countries) }\end{array}$ & $\begin{array}{l}\text { Lower Middle Income } \\
\text { (26 Countries) }\end{array}$ & $\begin{array}{l}\text { Lower Income } \\
\text { (16 Countries) }\end{array}$ \\
\hline Australia & Albania & Armenia & Burundi \\
\hline Austria & Algeria & Bangladesh & Central African Republic \\
\hline Barbados & Argentina & Bolivia & Guinea-Bissau \\
\hline Belgium & Botswana & Cameroon & Haiti \\
\hline Canada & Brazil & Cote d'Ivoire & Madagascar \\
\hline Chile & Bulgaria & Egypt & Malawi \\
\hline Croatia & China & El Salvador & Mali \\
\hline Cyprus & Colombia & Ghana & Mozambique \\
\hline Czech Republic & Costa Rica & Guatemala & Nepal \\
\hline Denmark & Dominican Republic & Honduras & Niger \\
\hline Estonia & Ecuador & India & Rwanda \\
\hline Finland & Fiji & Indonesia & Senegal \\
\hline France & Georgia & Kenya & Sierra Leone \\
\hline Germany & Guyana & Mongolia & Tanzania \\
\hline Greece & Iran & Morocco & Uganda \\
\hline Hungary & Jamaica & Nicaragua & Zimbabwe \\
\hline Iceland & Jordan & Nigeria & \\
\hline Ireland & Macedonia & Pakistan & \\
\hline Israel & Malaysia & Papua New Guinea & \\
\hline Italy & Mauritius & Philippines & \\
\hline Japan & Mexico & Sri Lanka & \\
\hline Korea, Republic of & Namibia & Syria & \\
\hline Latvia & Panama & Tunisia & \\
\hline Lithuania & Paraguay & Ukraine & \\
\hline Luxembourg & Peru & Vietnam & \\
\hline Malta & Romania & Zambia & \\
\hline Netherlands & Russia & & \\
\hline New Zealand & South Africa & & \\
\hline Norway & Thailand & & \\
\hline Poland & Turkey & & \\
\hline Portugal & Venezuela & & \\
\hline \multicolumn{4}{|l|}{ Singapore } \\
\hline \multicolumn{4}{|l|}{ Slovakia } \\
\hline \multicolumn{4}{|l|}{ Slovenia } \\
\hline \multicolumn{4}{|l|}{ Spain } \\
\hline \multicolumn{4}{|l|}{ Sweden } \\
\hline \multicolumn{4}{|l|}{ Switzerland } \\
\hline \multicolumn{4}{|l|}{ Taiwan } \\
\hline \multicolumn{4}{|l|}{ Trinidad and Tobago } \\
\hline \multicolumn{4}{|l|}{ United Kingdom } \\
\hline \multicolumn{4}{|l|}{ United States } \\
\hline Uruguay & & & \\
\hline
\end{tabular}

\section{References}

Acemoglu, Daron, Simon Johnson, and James A. Robinson. 2005. Institutions as a Fundamental Cause of Long-Run Growth. In Handbook of Economic Growth. Edited by Philippe Aghion and Steven N. Durlauf. Amsterdam: Elsevier B.V., vol. 1A, pp. 386-471.

Acemoglu, Daron, Suresh Naidu, Pascual Restrepo, and James A. Robinson. 2015. Democracy, redistribution, and inequality. In Handbook of Income Distribution. Edited by Anthony B. Atkinson and François Bourguignon. Amsterdam: Elsevier Ltd., vol. 2, pp. 1885-966.

Ahmad, Mahyudin. 2016. Middle Income Trap and Income Inequality: Empirical Evidence on the Distributional Effect of Economic Liberalization and Political Regime. MPRA Working Paper Series; WP No. 764; Munich: University Library of Munich, pp. 1-34. 
Amendola, Adalgiso, Joshy Easaw, and Antonio Savoia. 2013. Inequality in developing economies: The role of institutional development. Public Choice 155: 43-60. [CrossRef]

Apergis, Nicholas, and Arusha Cooray. 2015. Economic Freedom and Income Inequality: Evidence from a Panel of Global Economies-A Linear and a Non-Linear Long-Run Analysis. Manchester School 85: 88-105. [CrossRef]

Arellano, Manuel, and Stephen Bond. 1991. Some Tests of Specification for Panel Data: Monte Carlo Evidence and an Application to Employment Equations. The Review of Economic Studies 58: 277-97. [CrossRef]

Arellano, Manuel, and Olympia Bover. 1995. Another look at the instrumental variable estimation of error-components models. Journal of Econometrics 68: 29-51. [CrossRef]

Babones, Salvatore J., and María José Alvarez-Rivadulla. 2007. Standardized Income Inequality Data for Use in Cross-National Research. Sociological Inquiry 77: 3-22. [CrossRef]

Balcázar, Carlos F. 2015. Long-Run Effects of Democracy on Income Inequality: Evidence from Repeated cross-Sections. World Bank Policy Research Working Paper; Washington: World Bank, vol. 7153.

Balcázar, Carlos F. 2016. Long-run effects of democracy on income inequality in Latin America. Journal of Economic Inequality 14: 289-307. [CrossRef]

Barro, Robert J., and Jong-Wha Lee. 2013. A new data set of educational attainment in the world, 1950-2010. Journal of Development Economics 104: 184-98. [CrossRef]

Bennett, Daniel L., and Richard J. Cebula. 2016. Misperceptions about capitalism, government and inequality. In Economic Behavior, Economic Freedom, and Entrepreneurship. Edited by Richard J. Cebula, Joshua C. Hall, Franklin G. Mixon and James E. Payne. Northampton: Edward Elgar, pp. 1-20.

Bennett, Daniel L., and Boris Nikolaev. 2016. On the ambiguous economic freedom-inequality relationship. Empirical Economics 1-38. [CrossRef]

Bennett, Daniel L., and Richard K. Vedder. 2013. A Dynamic Analysis of Economic Freedom and Income Inequality in the 50 U.S. States: Evidence of a Parabolic Relationship. The Journal of Regional Analysis and Policy 43: 42-55. [CrossRef]

Berggren, Niclas. 1999. Economic freedom and equality: Friends or foes? Public Choice 100: 203-23. [CrossRef]

Bergh, Andreas, and Therese Nilsson. 2010. Do liberalization and globalization increase income inequality? European Journal of Political Economy 26: 488-505. [CrossRef]

Blundell, Richard, and Stephen Bond. 1998. Initial conditions and moment restrictions in dynamic panel data models. Journal of Econometrics 87: 115-143. [CrossRef]

Boix, Carles, Michael K. Miller, and Sebastian Rosato. 2013. A Complete Data Set of Political Regimes, 1800-2007. Comparative Political Studies 46: 1523-54. [CrossRef]

Calderón, César, and Alberto Chong. 2009. Labor market institutions and income inequality: An empirical exploration. Public Choice 138: 65-81. [CrossRef]

Carter, John R. 2006. An empirical note on economic freedom and income inequality. Public Choice 130: 163-177. [CrossRef]

Cheibub, José Antonio, Jennifer Gandhi, and James Raymond Vreeland. 2010. Democracy and dictatorship revisited. Public Choice 143: 67-101. [CrossRef]

Clark, J. R., and Robert A. Lawson. 2008. The Impact of Economic Growth, Tax Policy and Economic Freedom on Income Inequality. The Journal of Private Enterprise 24: 23-31.

Doucouliagos, Hristos, and Mehmet Ali Ulubasoglu. 2008. Democracy and Economic Growth: A Meta-Analysis. American Journal of Political Science 52: 61-83. [CrossRef]

Feenstra, Robert, Robert Inklaar, and Marcel Timmer. 2015. the Next Generation of the Penn World Table. National Bureau of Economic Research 105: 3150-82. [CrossRef]

Galbraith, James K., Béatrice Halbach, Aleksandra Malinowska, Amin Shams, and Wenjie Zhang. 2014. UTIP Global Inequality Data Sets 1963-2008:Updates, Revisions and Quality Checks. Austin: The University of Texas at Austin.

Gerry, Christopher J., and Tomasz M. Mickiewicz. 2008. Inequality, democracy and taxation: Lessons from the post-communist transition. Europe-Asia Studies 60: 89-111. [CrossRef]

Gradstein, Mark, and Branco Milanovic. 2004. Does libertè=egalité? A survey of the empirical links between democracy and inequality with some evidence on the transition economies. Journal of Economic Surveys 18: 515-537. [CrossRef]

Gwartney, James, Joshua Hall, and Robert Lawson. 2010. Economic Freedom in the World: 2010 Annual Report. Vancouver: The Fraser Institute. 
Hadenius, Axel, and Jan Teorell. 2007. Pathways from Authoritarianism. Journal of Democracy 18: 143-56. [CrossRef]

Holcombe, Randall G., and Christopher J. Boudreaux. 2016. Market institutions and income inequality. Journal of Institutional Economics 12: 263-276. [CrossRef]

Islam, Muhammed N. 2016. Does democracy reduce income inequality? Empirical Economics 51: 1-20. [CrossRef]

Jenkins, Stephen P. 2015. World income inequality databases: An assessment of WIID and SWIID. Journal of Economic Inequality 13: 629-71. [CrossRef]

Lee, Cheol-Sung. 2005. Income Inequality, Democracy, and Public Sector Size. American Economic Review 70: 158-181. [CrossRef]

Marshall, Monty G., and Keith Jaggers. 2014. Polity IV Project: Political Regime Characteristics and Transitions 1800-2014. Available online: http://www.systemicpeace.org/polity/polity4.htm (accessed on 20 March 2016).

Meschi, Elena, and Marco Vivarelli. 2009. Trade and Income Inequality in Developing Countries. World Development 37: 287-302. [CrossRef]

Reuveny, Rafael, and Quan Li. 2003. Economic openness, democracy, and income inequality - An empirical analysis. Comparative Political Studies 36: 575-601. [CrossRef]

Roodman, David. 2009. A note on the theme of too many instruments. Oxford Bulletin of Economics and Statistics 71: 135-58. [CrossRef]

Savoia, Antonio, Joshy Easaw, and Andrew Mckay. 2010. Inequality, Democracy, and Institutions: A Critical Review of Recent Research. World Development 38: 142-54. [CrossRef]

Scully, Gerald W. 2002. Economic Freedom, Government Policy and the Trade-Off Between Equity and Economic Growth. Public Choice 113: 77-96. [CrossRef]

Solt, Frederick. 2014. The Standardized World Income Inequality Database. University of Iowa Working Paper, SWIID Version 5.0; Iowa City: University of Iowa.

Sturm, Jan-Egbert, and Jakob De Haan. 2015. Income Inequality, Capitalism, and Ethno-Linguistic Fractionalization. American Economic Review 105: 593-97. [CrossRef]

Timmons, Jeffrey F. 2010. Does Democracy Reduce Economic Inequality. British Journal of Political Science 40: 741-57. [CrossRef]

Windmeijer, Frank. 2005. A finite sample correction for the variance of linear efficient two-step GMM estimators. Journal of Econometrics 126: 25-51. [CrossRef]

World Bank. 2016. World Development Indicators. Washington: World Bank. 